WATER QUALITY AND DEPTH TO WATER, 2001-02, AND GRAPHS OF SELECTED CONSTITUENTS AND DEPTH TO WATER, PERIOD OF RECORD THROUGH 2002, IN SELECTED WELLS, EASTERN BERNALILLO COUNTY, NEW MEXICO

U.S. DEPARTMENT OF THE INTERIOR U.S. GEOLOGICAL SURVEY

Open-File Report 03-81

Prepared in cooperation with BERNALILLO COUNTY 


\section{WATER QUALITY AND DEPTH TO WATER, 2001-02, AND GRAPHS OF SELECTED CONSTITUENTS AND DEPTH TO WATER, PERIOD OF RECORD THROUGH 2002, IN SELECTED WELLS, EASTERN BERNALILLO COUNTY, NEW MEXICO}

By Paul J. Blanchard

U.S. GEOLOGICAL SURVEY

Open-File Report 03-81

Prepared in cooperation with

BERNALILLO COUNTY 


\section{U.S. DEPARTMENT OF THE INTERIOR \\ GALE A. NORTON, Secretary}

U.S. GEOLOGICAL SURVEY

Charles G. Groat, Director

The use of firm, trade, and brand names in this report is for identification purposes only and does not constitute endorsement by the U.S. Geological Survey.

For additional information write to:

District Chief

U.S. Geological Survey

Water Resources Division

5338 Montgomery Blvd. NE, Suite 400

Albuquerque, NM 87109-1311
Copies of this report can be purchased from:

U.S. Geological Survey

Information Services

Box 25286

Denver, CO 80225-0286

Information regarding research and data-collection programs of the U.S. Geological Survey is available on the Internet via the World Wide Web. You may connect to the home page for the New Mexico District Office using the URL http://nm.water.usgs.gov. 


\section{CONTENTS}

Introduction

Purpose and scope

Description of study area.

Monitoring-well network and data collection during 2001-02 _........................................................................... 3

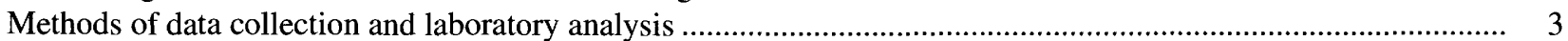

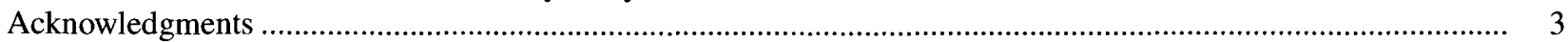

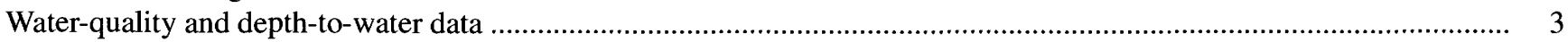

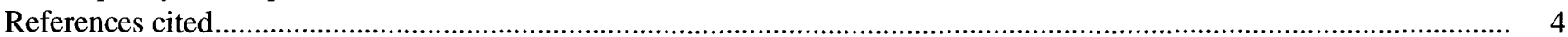

\section{FIGURES}

1. Map showing location of study area and monitoring wells, eastern Bernalillo County, New Mexico ................... 2

2-18. Graphs and hydrographs showing concentrations of selected constituents and depth to water in:

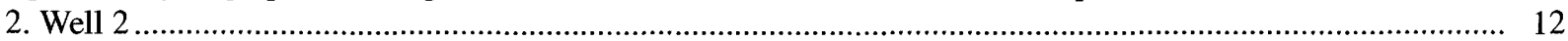

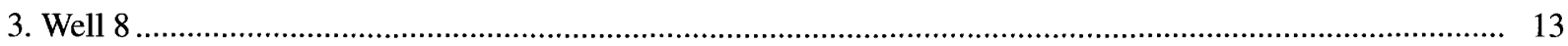

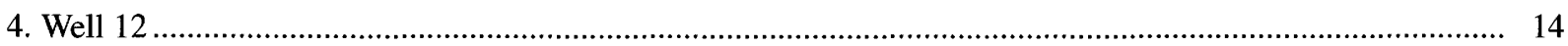

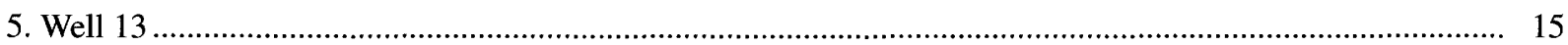

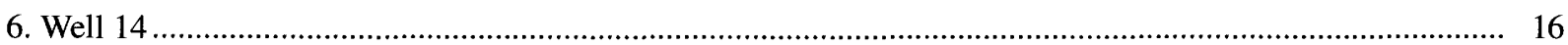

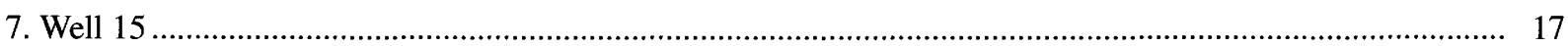

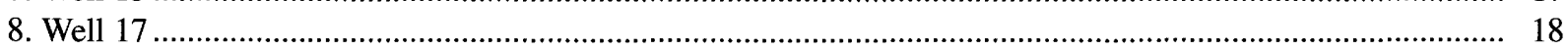

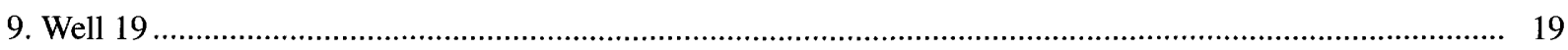

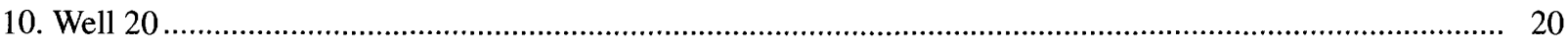

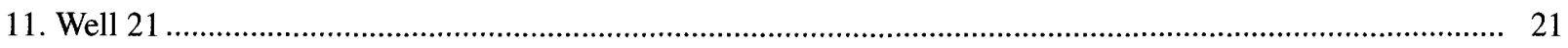

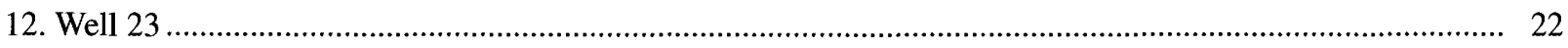

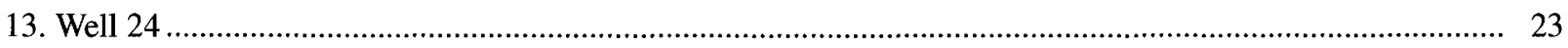

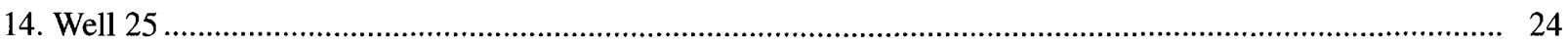

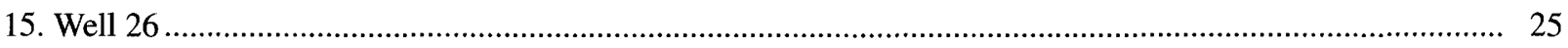

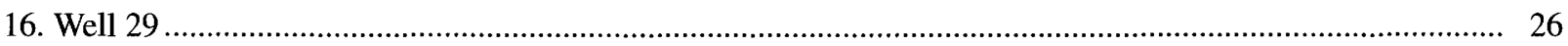

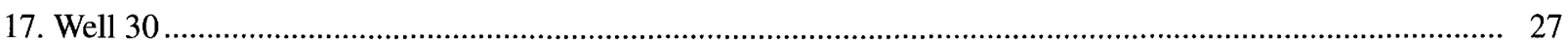

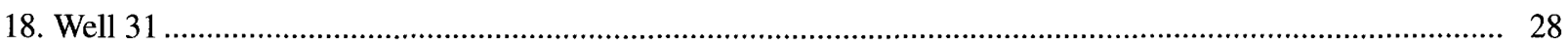

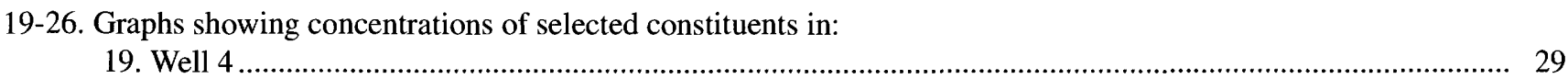

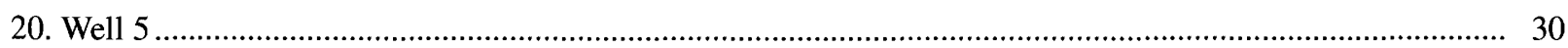

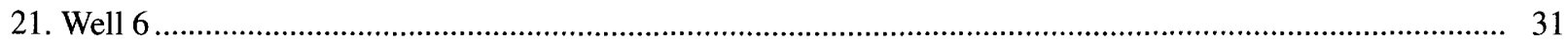

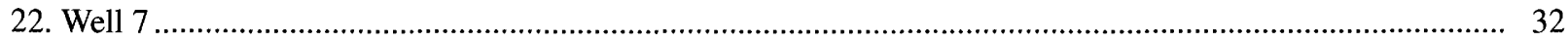

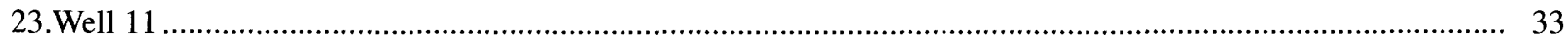

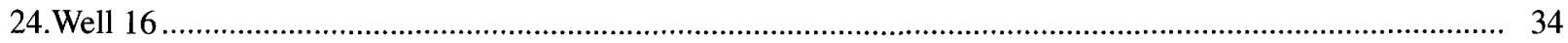

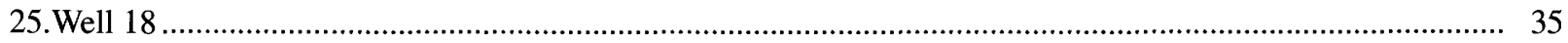

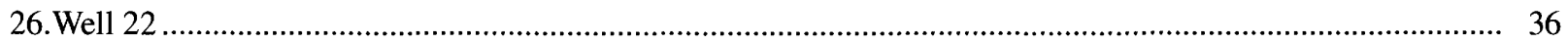

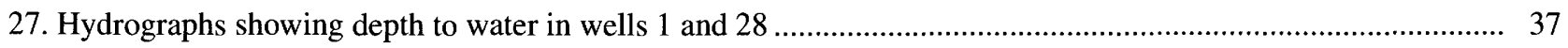

\section{TABLES}

1. Selected records of wells in the monitoring network ...................................................................................

2. Results of field determinations and laboratory analyses of samples collected from monitoring wells, 2001-02 ... 6 
CONVERSION FACTORS, DATUMS, AND ABBREVIATED WATER-QUALITY UNITS

\begin{tabular}{rrrl}
\hline Multiply & \multicolumn{1}{c}{ By } & To obtain \\
foot $(\mathrm{ft})$ & 0.3048 & meter $(\mathrm{m})$ \\
mile $(\mathrm{mi})$ & 1.609 & kilometer $(\mathrm{km})$ \\
square mile $\left(\mathrm{mi}^{2}\right)$ & 259.0 & hectare (ha) \\
square mile $\left(\mathrm{mi}^{2}\right)$ & 2.590 & square kilometer $\left(\mathrm{km}^{2}\right)$ \\
\hline
\end{tabular}

Vertical coordinate information is referenced to the National Geodetic Vertical Datum of 1929 (NGVD 29).

Horizontal coordinate information is referenced to the North American Datum of 1927 (NAD 27).

Temperature in degrees Fahrenheit $\left({ }^{\circ} \mathrm{F}\right)$ can be converted to degrees Celsius $\left({ }^{\circ} \mathrm{C}\right)$ as follows:

$$
\begin{aligned}
& { }^{\circ} \mathrm{C}=\left({ }^{\circ} \mathrm{F}-32\right) / 1.8 \\
& { }^{\circ} \mathrm{F}=\left(1.8 \times{ }^{\circ} \mathrm{C}\right)+32
\end{aligned}
$$

Altitude, as used in this report, refers to distance above or below sea level.

Specific conductance is given in microsiemens per centimeter at 25 degrees Celsius $(\mu \mathrm{S} / \mathrm{cm}$ at $25^{\circ} \mathrm{C}$ ).

Concentrations of chemical constituents in water are given either in milligrams per liter $(\mathrm{mg} / \mathrm{L})$ or micrograms per liter $(\mu \mathrm{g} / \mathrm{L})$. 


\title{
WATER QUALITY AND DEPTH TO WATER, 2001-02, AND GRAPHS OF SELECTED CONSTITUENTS AND DEPTH TO WATER, PERIOD OF RECORD THROUGH 2002, IN SELECTED WELLS, EASTERN BERNALILLO COUNTY, NEW MEXICO
}

\author{
By Paul J. Blanchard
}

\section{ABSTRACT}

Since 1990, the U.S. Geological Survey, in cooperation with the Bernalillo County Environmental Health Department, has periodically collected water samples for laboratory chemical analysis from a network of 20 wells in eastern Bernalillo County to monitor the effects of domestic wastewater disposal. The depth to water also has been measured in these wells to monitor the effects of ground-water withdrawals. From September 2001 through June 2002, water samples were again collected from and depth to water was measured in these wells where access was available. Two wells were removed from the network because water-level measurement and sample collection were no longer feasible, and 13 wells were added to the network. Of the 31 wells in the network, water samples were collected from 8 wells, depth to water was measured in 5 wells, and both activities were conducted at 18 wells. Sample analyses included determination of concentrations of dissolved nitrite plus nitrate, dissolved chloride, and total organic carbon, which frequently are used as indicators of contamination from domestic wastewater disposal. Concentrations of dissolved nitrite plus nitrate ranged from 0.050 to 20.0 milligrams per liter, and concentrations in two samples exceeded the U.S. Environmental Protection Agency primary drinking water standard of 10 milligrams per liter.

Concentrations of dissolved chloride ranged from 8.2 to 400 milligrams per liter and concentrations in four samples exceeded the U.S. Environmental Protection Agency secondary drinking water standard of 250 milligrams per liter. The concentration of total organic carbon in one sample was 9.4 milligrams per liter; concentrations in all other samples were 4.3 milligrams per liter or smaller. No U.S. Environmental Protection Agency drinking water standards have been established for organic carbon. Primary and secondary drinking water standards pertain to human health concerns and esthetics, respectively.

\section{INTRODUCTION}

Unincorporated areas of eastern Bernalillo County, New Mexico, have undergone rapid development and attendant population increases in recent years, and the demand for water and the potential for contamination of ground water have increased accordingly. Water for most homes in these unincorporated areas is supplied by individual domestic wells, and most homes use septic systems for the disposal of wastewater. Bernalillo County officials recognize the importance of monitoring the effects of increased ground-water use on ground-water levels and the effects of domestic wastewater disposal on groundwater quality in the east mountain area.

Accordingly, the U.S. Geological Survey (USGS), in cooperation with the Bernalillo County Environmental Health Department, entered into a cooperative agreement to collect and interpret groundwater data in eastern Bernalillo County (fig. 1). From January 1990 through June 1993, the USGS collected and analyzed monthly ground-water samples and measured monthly depths to ground water in 20 domestic supply wells throughout eastern Bernalillo County (Kues and Garcia, 1995). These wells were established as the monitoring-well network, and data have been collected from them periodically since June 1993 (Rankin, 1996; 2000).

\section{Purpose and Scope}

This report presents ground-water-level and ground-water-quality data collected in the eastern Bernalillo County area during 2001-02. Data were collected from 18 of the 20 wells in the previously established monitoring-well network and from 13 wells that were added to the network in 2001-02 (fig. 1). Graphs showing concentrations of total and dissolved nitrite plus nitrate, dissolved chloride, and total organic carbon and hydrographs showing depths to ground water are presented for the period of record 


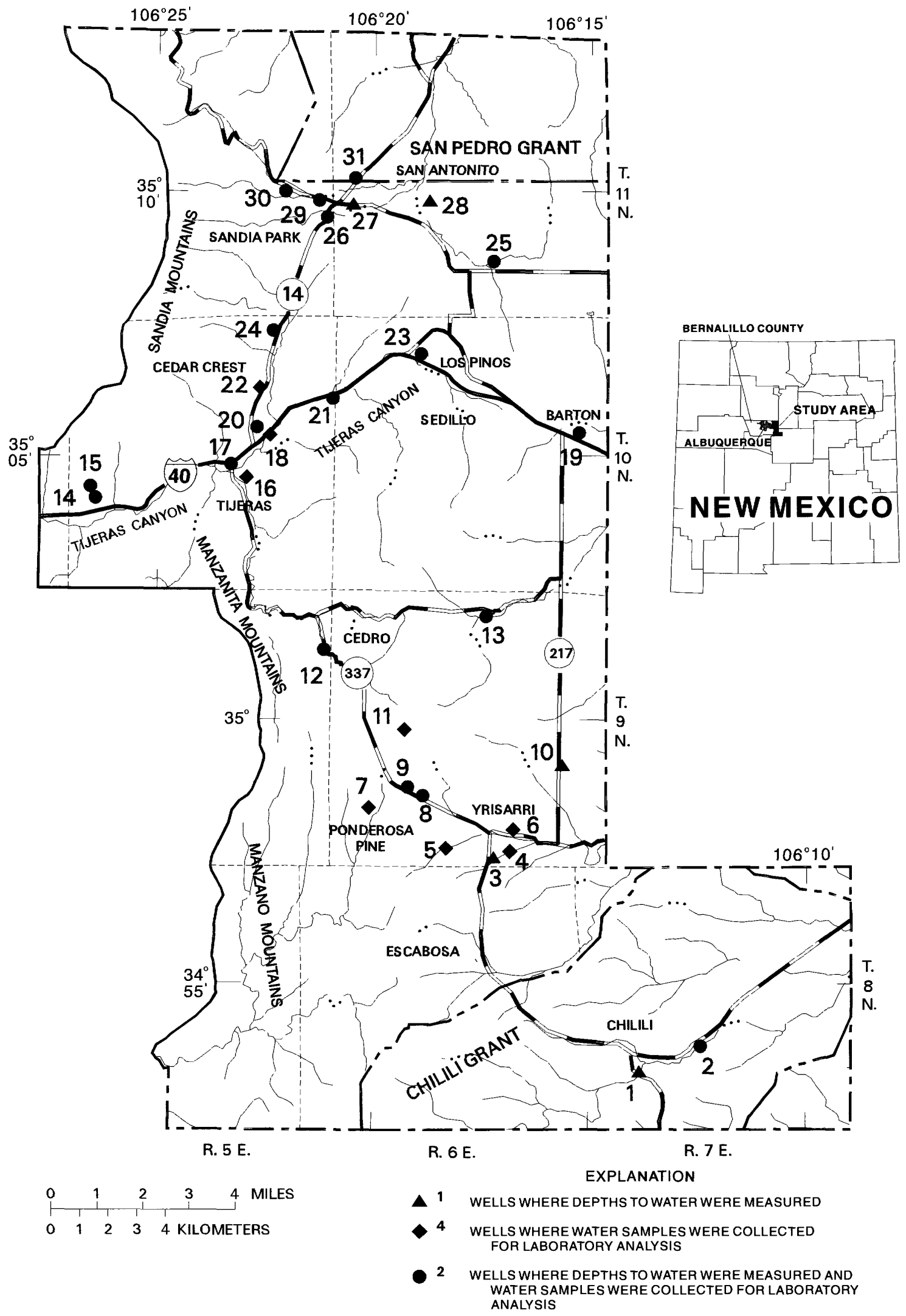

Figure 1. Location of study area and monitoring wells, eastern Bernalillo County, New Mexico. 
of each well in the network where water samples had been collected and analyzed and (or) depth to water had been measured before 2001. The period of record includes data collected prior to 1990 for seven wells.

\section{Description of Study Area}

The eastern Bernalillo County study area comprises about 150 square miles and extends to the county boundaries on the north, east, and south (fig. 1). The study area is bounded on the west by the crests of the Sandia, Manzanita, and Manzano Mountains. The land surface slopes away from the mountains toward the east, and these slopes are cut by drainages flowing eastward out of the mountains.

Soil and unconsolidated alluvial deposits overlie fractured limestone in most of the study area. In the central part of the area, primarily north of Interstate Highway 40 and east of New Mexico Highway 14, the uppermost consolidated geologic units consist of fractured sandstone and shale. Igneous and metamorphic rocks crop out in Tijeras Canyon, which separates the southern terminus of the Sandia Mountains from the northern terminus of the Manzanita Mountains.

\section{Monitoring-Well Network and Data Collection during 2001-02}

Currently (2002), the network consists of 31 wells at which either water samples were collected to be analyzed ( 8 wells), depth to water was measured (5 wells), or both (18 wells) (fig. 1). Selected records for the 31 wells are listed in table 1. Eighteen wells were included from the previous network of 20 wells, and 13 wells were added to the network. Data were collected prior to 2001 at 9 of the 13 wells added to the network.

Water samples could not be collected at five wells because of nonoperating pumps, inaccessibility to water before it entered a holding tank, or water softener. In addition, water-level measurements were not feasible at eight wells because water levels had not fully recovered between pumping cycles (four wells), condensation was present in the casing (one well), the well head was not accessible (one well), the water level was higher than land surface and the well was under pressure (one well), or the well owner did not grant permission to measure the depth to water (one well).

\section{Methods of Data Collection and Laboratory Analysis}

Depths to water in wells were measured using a steel tape. Temperature, specific conductance, and $\mathrm{pH}$ were measured in the field according to standard USGS procedures (Wilde and Radtke, 1998), and groundwater samples were collected, processed, and shipped according to established USGS procedures (Wilde and others, 1998; 1999). Water samples were collected using the pumps installed in the wells for water supply. Samples were collected as close to the well as access would allow and prior to any water treatment.

Water samples were analyzed for concentrations of major ions, selected species of nitrogen and phosphorus, total organic carbon, acid neutralizing capacity, and the trace elements arsenic, boron, iron, and manganese. Hardness and concentrations of dissolved solids were calculated from analytical results. The USGS National Water Quality Laboratory in Lakewood, Colorado, conducted all analyses according to standard procedures (Fishman and Friedman, 1989).

\section{Acknowledgments}

The cooperation of private well owners, whose permission facilitated collection of water samples from and measurement of depths to water in their wells, is gratefully acknowledged. The cooperation and assistance of employees of the U.S. Forest Service and the U.S. Postal Service also are gratefully acknowledged.

\section{WATER-QUALITY AND DEPTH-TO- WATER DATA}

Results of depth-to-water measurements conducted during 2001-02 are listed in table 1. Field measurements and chemical analyses of samples conducted during 2001-02 are listed in table 2.

Graphs showing concentrations of total and dissolved nitrite plus nitrate, dissolved chloride, total organic carbon (chemical constituents that are common indicators of contamination by sewage effluent), and hydrographs showing depths to water in wells $2,8,12$ $15,17,19-21,23-26$, and 29-31 are shown in figures 2 - 
18. Graphs showing concentrations of these chemical constituents in wells $4-7,11,16,18$, and 22 are shown in figures 19-26, and hydrographs of depths to water in wells 1 and 28 are shown in figure 27. Data for the entire period of record are shown on each graph or hydrograph.

For samples collected during 2001-02, concentrations of dissolved nitrite were estimated or confirmed to be less than 0.01 milligram per liter $(\mathrm{mg} / \mathrm{L})$ in all samples (table 2$)$. Concentrations of dissolved nitrite plus nitrate ranged from 0.050 to 20.0 $\mathrm{mg} / \mathrm{L}$ and were less than $1 \mathrm{mg} / \mathrm{L}$ in 10 samples. Concentrations in nine samples ranged from 1.34 to $3.96 \mathrm{mg} / \mathrm{L}$ and in five samples ranged from 7.58 to 9.61 $\mathrm{mg} / \mathrm{L}$. Concentrations in two samples were $16.5 \mathrm{mg} / \mathrm{L}$ in well 14 and $20.0 \mathrm{mg} / \mathrm{L}$ in well 26, which exceed the current (2002) U.S. Environmental Protection Agency (USEPA) primary drinking water standard of $10 \mathrm{mg} / \mathrm{L}$. Primary drinking water standards pertain to human health concerns.

Concentrations of dissolved chloride ranged from 8.2 to $400 \mathrm{mg} / \mathrm{L}$ and were less than $100 \mathrm{mg} / \mathrm{L}$ in 11 samples. Concentrations in eight samples ranged from 109 to $184 \mathrm{mg} / \mathrm{L}$ and in three samples ranged from 213 to $244 \mathrm{mg} / \mathrm{L}$. Concentrations in four samples, $266 \mathrm{mg} / \mathrm{L}$ in well $14,328 \mathrm{mg} / \mathrm{L}$ in well $21,365 \mathrm{mg} / \mathrm{L}$ in well 23 , and $400 \mathrm{mg} / \mathrm{L}$ in well 19 , exceed the current (2002) USEPA secondary drinking water standard for chloride of $250 \mathrm{mg} / \mathrm{L}$. Secondary drinking water standards pertain to esthetics.

The concentration of total organic carbon in one sample was $9.4 \mathrm{mg} / \mathrm{L}$. Concentrations in all other samples were $4.3 \mathrm{mg} / \mathrm{L}$ or smaller. No USEPA drinking water standards have been established for organic carbon.

The concentration of dissolved arsenic was less than 2 micrograms per liter $(\mu \mathrm{g} / \mathrm{L})$ in all wells except well $4(7.6 \mu \mathrm{g} / \mathrm{L})$, well $7(5.2 \mu \mathrm{g} / \mathrm{L})$, and well 8 (69.6 $\mu \mathrm{g} / \mathrm{L})$. Dissolved-arsenic concentrations in all wells except well 8 were less than the current (2002) USEPA primary drinking water standard of $10 \mu \mathrm{g} / \mathrm{L}$.

\section{REFERENCES CITED}

Fishman, M.J., and Friedman, L.C., eds., 1989, Methods for the determination of inorganic substances in water and fluvial sediments: U.S. Geological Survey Techniques of Water-Resources Investigations, book 5, chap. A1, $545 \mathrm{p}$.
Kues, G.E., and Garcia, B.M., 1995, Ground-water quality and ground-water-level data, Bernalillo County, central New Mexico, 1990-93: U.S. Geological Survey OpenFile Report 95-385, 76 p.

Rankin, D.R., 1996, Water-quality and ground-water-level data, Bernalillo County, central New Mexico, 1995: U.S. Geological Survey Open-File Report 96-578, 14 p. -2000 , Water-quality and ground-water-level trends, 1990-99, and data collected from 1995 through 1999 , east mountain area, Bernalillo County, central New Mexico: U.S. Geological Survey Open-File Report 00476, $41 \mathrm{p}$.

Wilde, F.D., and Radtke, D.B., eds., 1998, National field manual for the collection of water-quality data: U.S. Geological Survey Techniques of Water-Resources Investigations, book 9, chap. A6, $220 \mathrm{p}$.

Wilde, F.D., Radtke, D.B., Gibs, J., and Iwatsubo, R.T., eds., 1998, National field manual for the collection of waterquality data: U.S. Geological Survey Techniques of Water-Resources Investigations, book 9, chap. A1-A3, $185 \mathrm{p}$.

1999 , National field manual for the collection of water-quality data: U.S. Geological Survey Techniques of Water-Resources Investigations, book 9, chap. A4A5, $231 \mathrm{p}$. 
Table 1. Selected records of wells in the monitoring network

[Altitude of land surface in feet above NGVD 29; depth of well and water level in feet below land surface; --, no data]

\section{Monitoring \\ network well number}

(fig. 1)
Well site
identifier
Altitude

of land Date well Depth Water surface constructed of well level
Date water level Well sampled measured in 2001-02

\begin{tabular}{|c|c|c|c|c|c|c|c|}
\hline 1 & 345319106135101 & 6,790 & -- & 100 & 19.88 & $5 / 29 / 2002$ & No \\
\hline 2 & 345348106122601 & 6,660 & $8 / 24 / 1974$ & 45 & 18.62 & $6 / 10 / 2002$ & Yes \\
\hline 3 & 345723106171301 & 7,260 & -- & -- & 96.55 & $6 / 28 / 2002$ & No \\
\hline 4 & 345726106170401 & 7,230 & -- & -- & -- & -- & Yes \\
\hline 5 & 345733106181901 & 7,280 & -- & 128 & -- & -- & Yes \\
\hline 6 & 345754106164601 & 7,220 & - & -- & -- & -- & Yes \\
\hline 7 & 345819106200601 & 7,420 & -- & -- & -- & -- & Yes \\
\hline 8 & 345833106185101 & 7,420 & $10 / 19 / 1979$ & 315 & 173.44 & $5 / 3 / 2002$ & Yes \\
\hline 9 & 345843106191201 & 7,510 & -- & -- & 269.95 & $5 / 13 / 2002$ & Yes \\
\hline 10 & 345908106153901 & 7,290 & -- & -- & 194.30 & $5 / 22 / 2002$ & No \\
\hline 11 & 345948106191701 & 7,680 & -- & -- & -- & - & Yes \\
\hline 12 & 350119106210901 & 7,060 & -- & -- & 32.31 & $4 / 19 / 2002$ & Yes \\
\hline 13 & 350157106172501 & 7,080 & -- & -- & 178.86 & $6 / 11 / 2002$ & Yes \\
\hline 14 & 350410106262601 & 6,030 & $1 / 1 / 1957$ & 120 & 71.63 & $6 / 28 / 2002$ & Yes \\
\hline 15 & 350423106263301 & 6,255 & $1 / 1 / 1960$ & 146 & 44.27 & $7 / 2 / 2002$ & Yes \\
\hline 16 & 350434106225701 & 6,350 & $3 / 18 / 1969$ & 253 & -- & - & Yes \\
\hline 17 & 350449106231901 & 6,355 & -- & -- & 28.50 & $7 / 2 / 2002$ & Yes \\
\hline 18 & 350522106222501 & 6,400 & -- & 73 & - & -- & Yes \\
\hline 19 & 350525106151701 & 6,775 & $7 / 28 / 1980$ & 275 & 142.09 & $5 / 10 / 2002$ & Yes \\
\hline 20 & 350531106224301 & 6,540 & -- & 160 & 41.92 & $4 / 19 / 2002$ & Yes \\
\hline 21 & 350604106205801 & 6,520 & -- & 85 & 34.48 & $5 / 31 / 2002$ & Yes \\
\hline 22 & 350615106223301 & 6,580 & $10 / 11 / 1967$ & 80 & -- & - & Yes \\
\hline 23 & 350655106185601 & 6,880 & - & 300 & 209.83 & $5 / 23 / 2002$ & Yes \\
\hline 24 & 350721106222101 & 6,765 & $1 / 1 / 1965$ & 200 & 9.96 & $6 / 22 / 2002$ & Yes \\
\hline 25 & 350840106171601 & 6,780 & $2 / 16 / 1977$ & 320 & 108.09 & $6 / 6 / 2002$ & Yes \\
\hline 26 & 350930106210701 & 6,860 & -- & 120 & 54.50 & $5 / 28 / 2002$ & Yes \\
\hline 27 & 350945106203101 & 6,790 & -- & - & 60.53 & $5 / 17 / 2002$ & No \\
\hline 28 & 350949106184501 & 6,700 & - & 280 & 180.10 & $5 / 17 / 2002$ & No \\
\hline 29 & 350949106211801 & 6,940 & - & 260 & 191.70 & $7 / 2 / 2002$ & Yes \\
\hline 30 & 351011106220401 & 7,100 & - & -- & 17.87 & $7 / 2 / 2002$ & Yes \\
\hline 31 & 351014106202801 & 6,798 & -- & -- & 46.82 & $5 / 20 / 2002$ & Yes \\
\hline
\end{tabular}




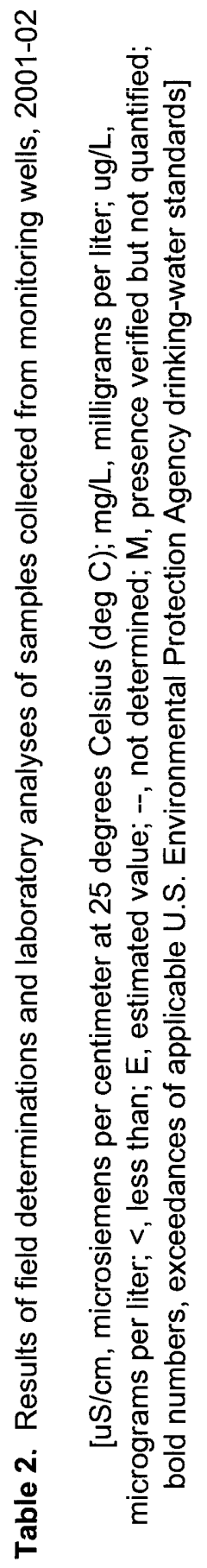

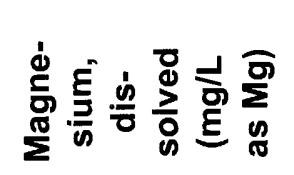

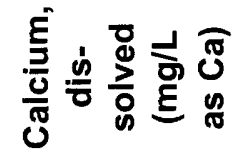

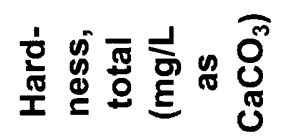

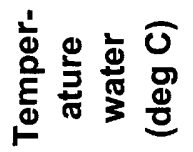

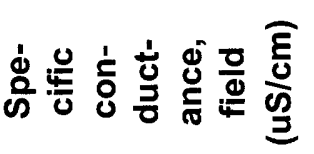

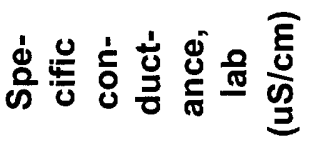

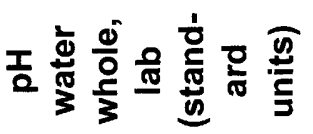

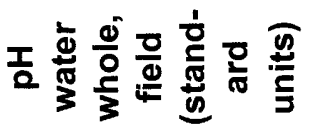

离

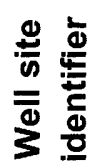

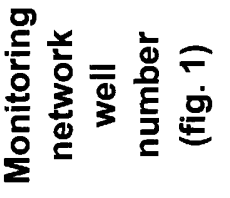

눈

요뭄ำ

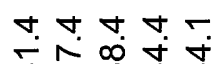

r.

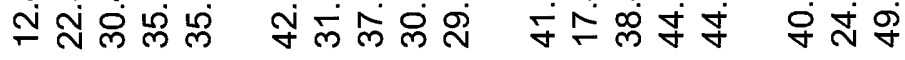

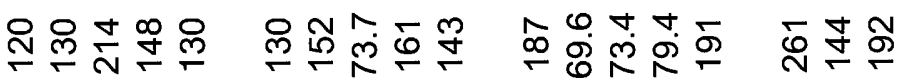

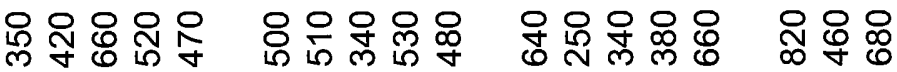



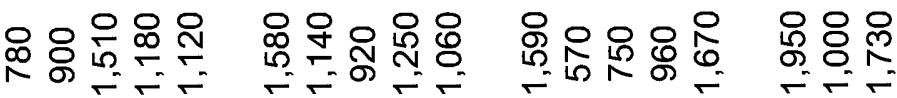

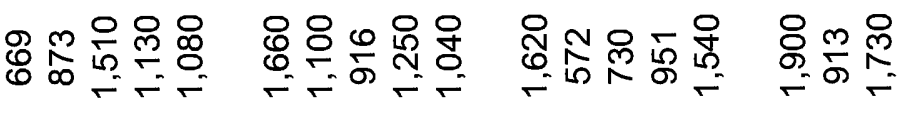

N⿴囗十心

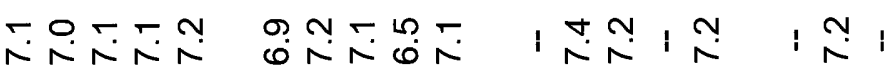

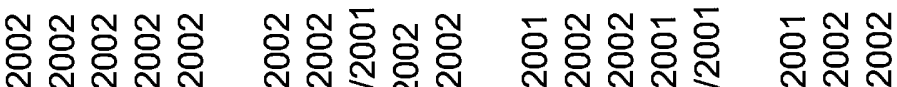

응

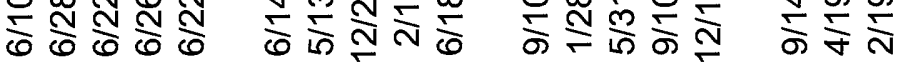

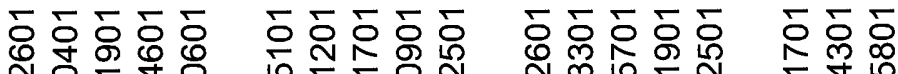

กำ

구의

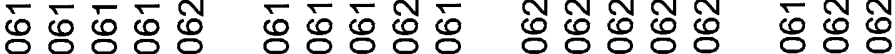

으은으응 은응으은 응으은으 응응

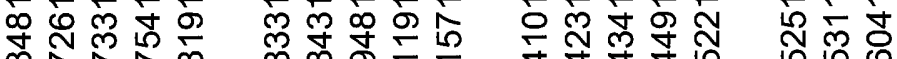

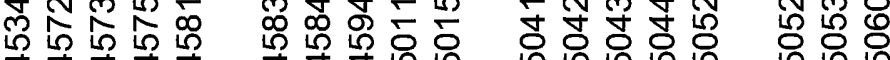

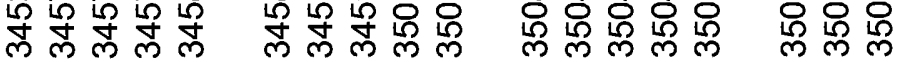

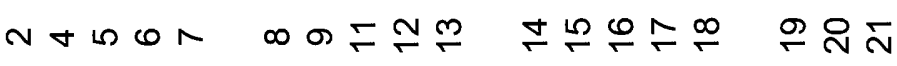




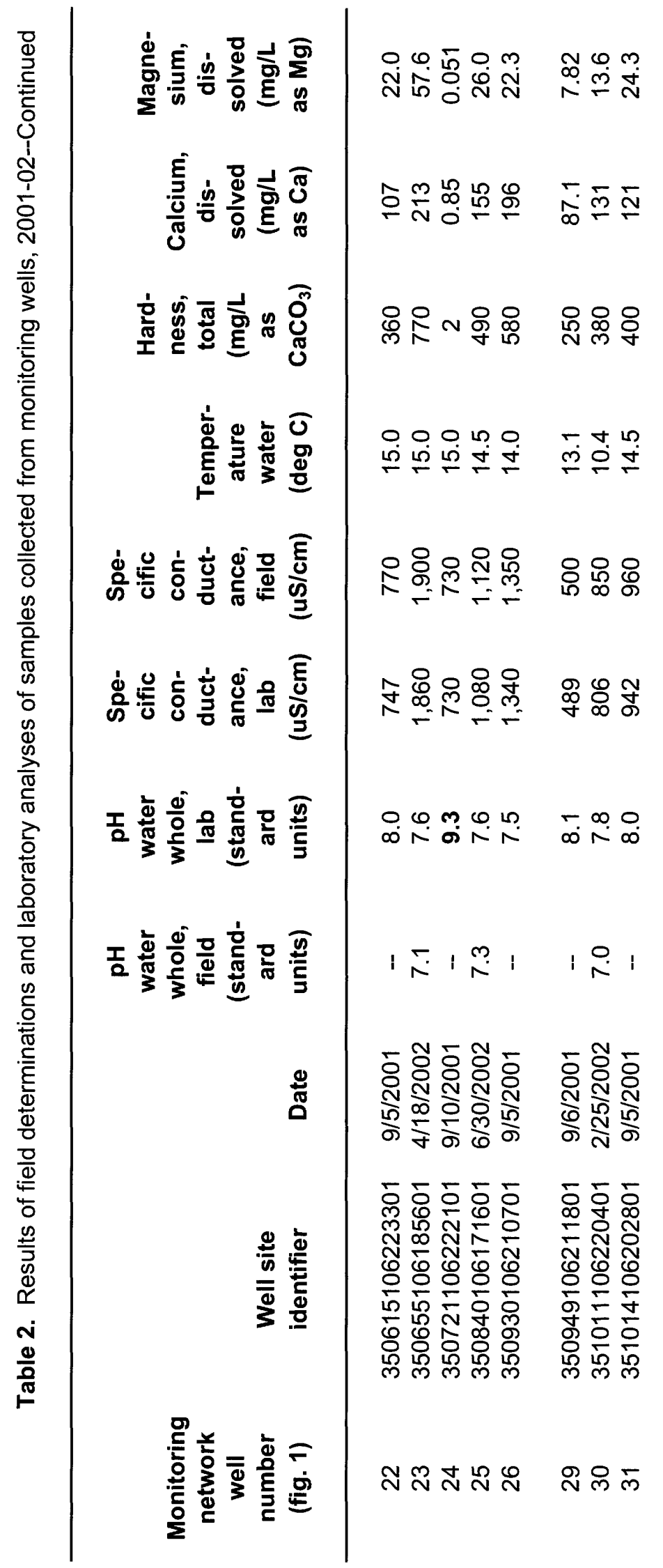




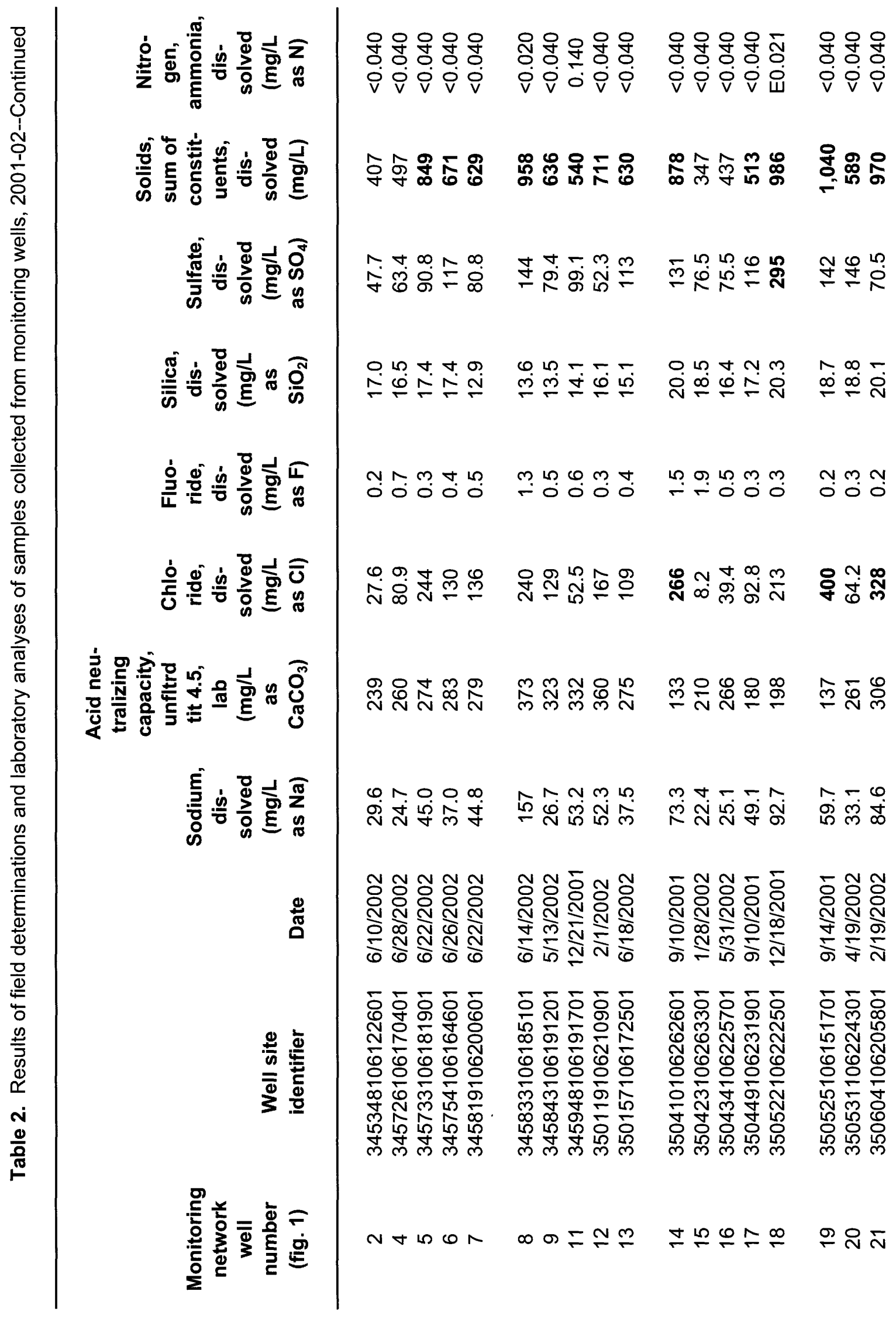




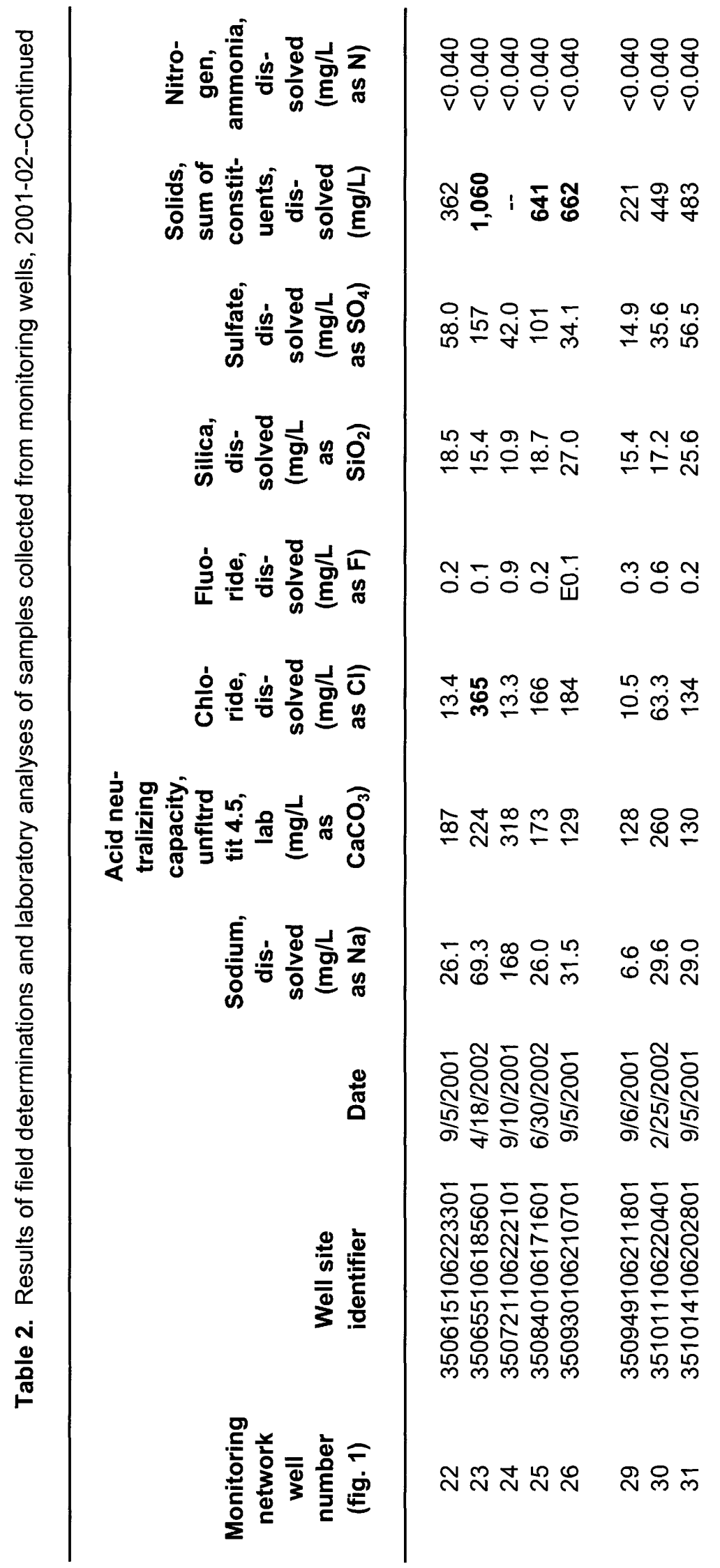




\begin{tabular}{|c|c|c|c|c|}
\hline 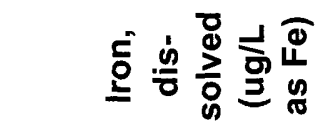 & 은 온유욤은 & 은 은 은 윤 은 & 응ㅇㅅ $\Sigma \frac{}{\mathrm{N}} \frac{\mathrm{O}}{\mathrm{v}}$ & 요 을 은 \\
\hline ㅎํㅇํㅇ & மల శా ద & 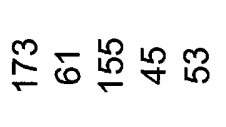 & స్ల ర్ల & 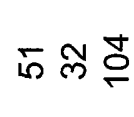 \\
\hline 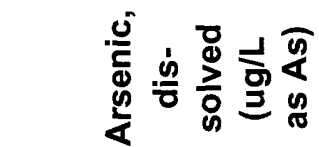 & 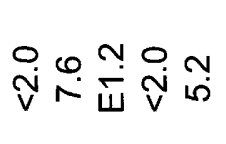 & 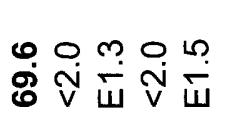 & 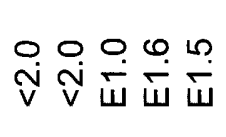 & 울요 \\
\hline 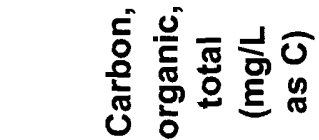 & 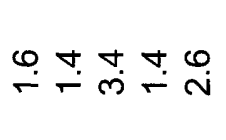 & 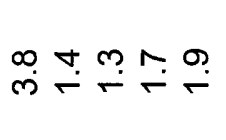 & 붕요 & ले \\
\hline 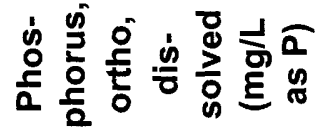 & 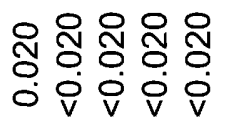 & 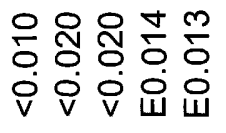 & 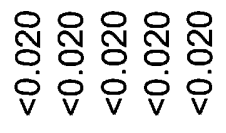 & 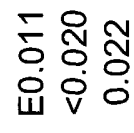 \\
\hline 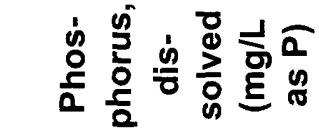 & $\begin{array}{l}\infty \\
\infty \\
\circ\end{array}$ & 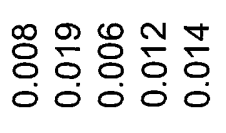 & 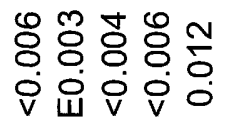 & 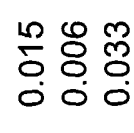 \\
\hline 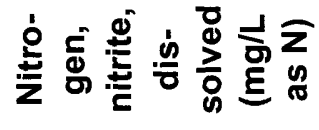 & $\begin{array}{l}\infty \\
0 \\
0\end{array}$ & 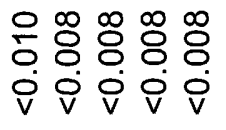 & 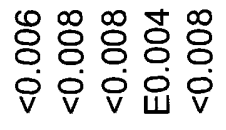 & 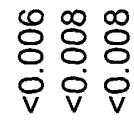 \\
\hline 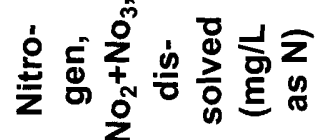 & 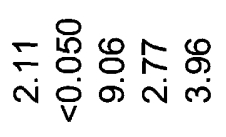 & 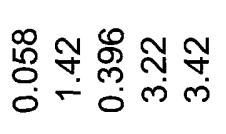 & 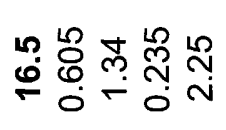 & 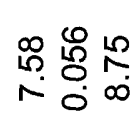 \\
\hline هัँ & 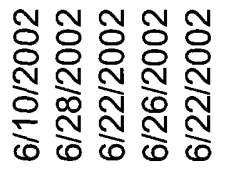 & 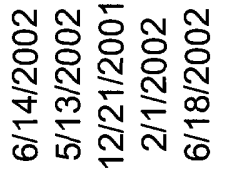 & 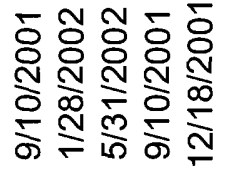 & 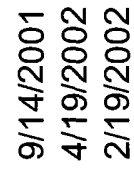 \\
\hline 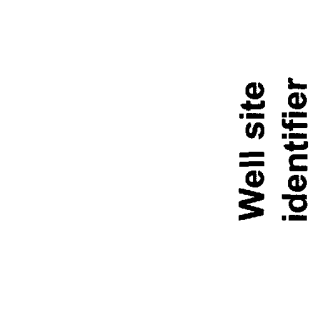 & 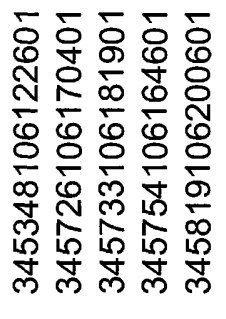 & 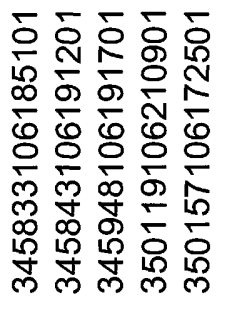 & 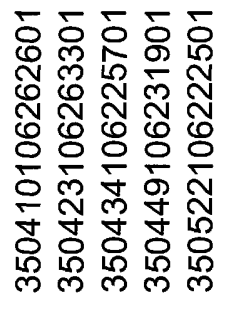 & 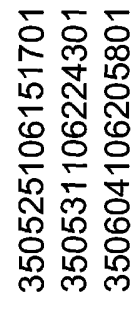 \\
\hline 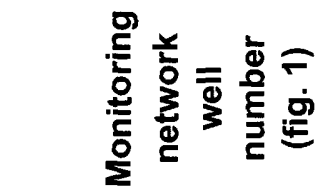 & $N \nabla L \sigma N$ & 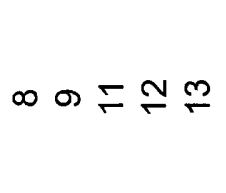 & $\underset{\sim}{\sim} \stackrel{\sim}{\leftarrow} \stackrel{\infty}{\leftarrow}$ & $\stackrel{g}{-}$ ㄱ \\
\hline
\end{tabular}




\begin{tabular}{|c|c|c|}
\hline 응 & 웅 웅은 은 은 & 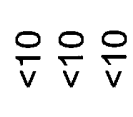 \\
\hline 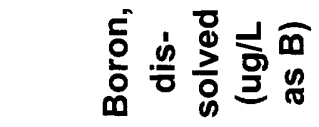 & 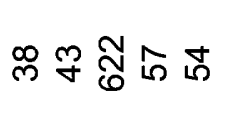 & 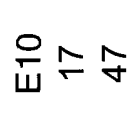 \\
\hline 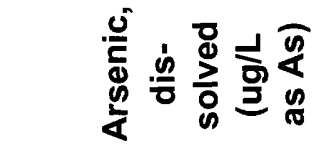 & 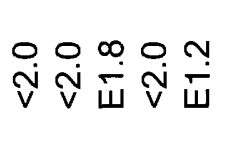 & 울우 \\
\hline 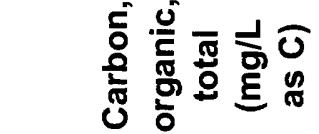 & ڤִ & 守 \\
\hline 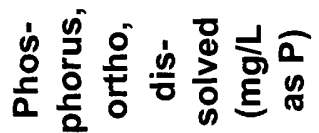 & 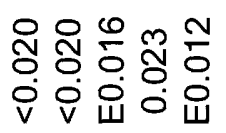 & 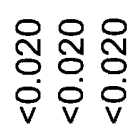 \\
\hline 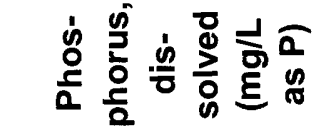 & 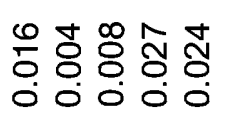 & 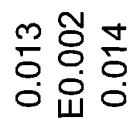 \\
\hline 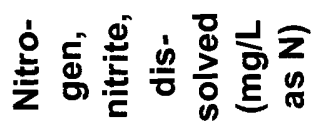 & 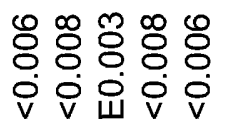 & 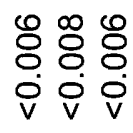 \\
\hline 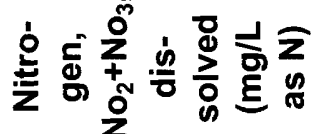 & 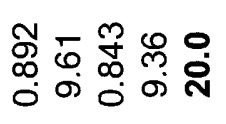 & 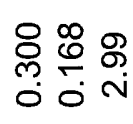 \\
\hline هั & 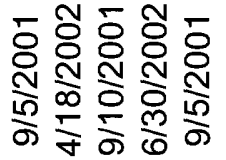 & 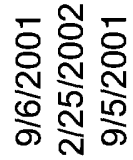 \\
\hline 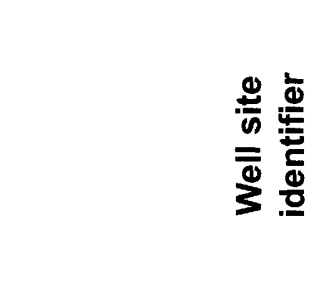 & 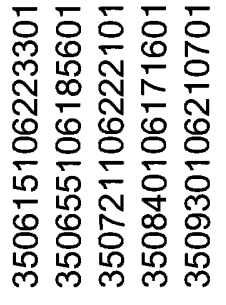 & 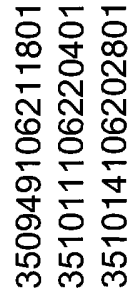 \\
\hline 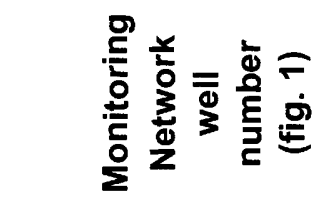 & స̃ $\stackrel{\sim}{\sim} \stackrel{\sim}{\sim} \stackrel{\sim}{N}$ & 규 ल \\
\hline
\end{tabular}



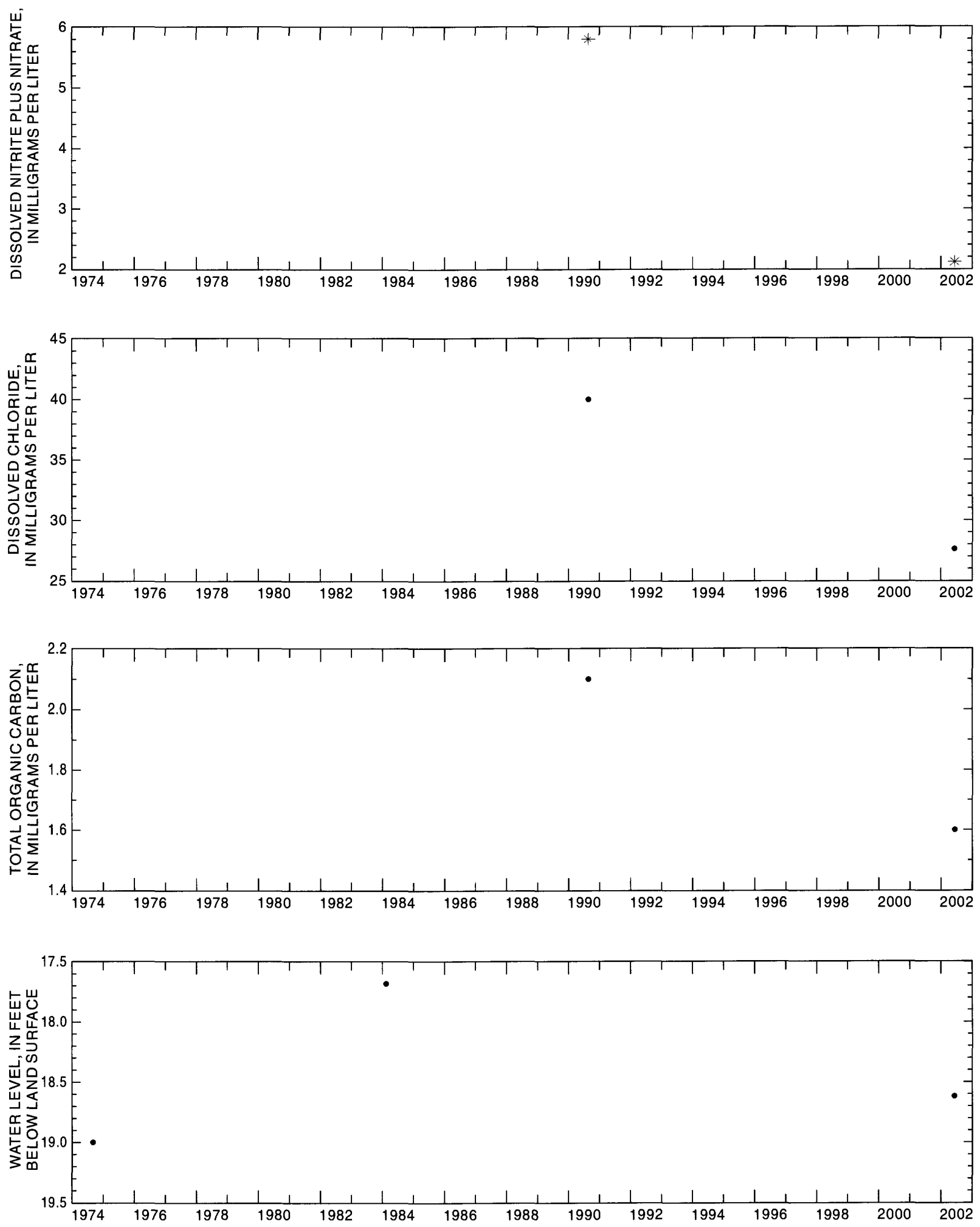

Figure 2. Concentrations of selected constituents and depth to water in well 2. 

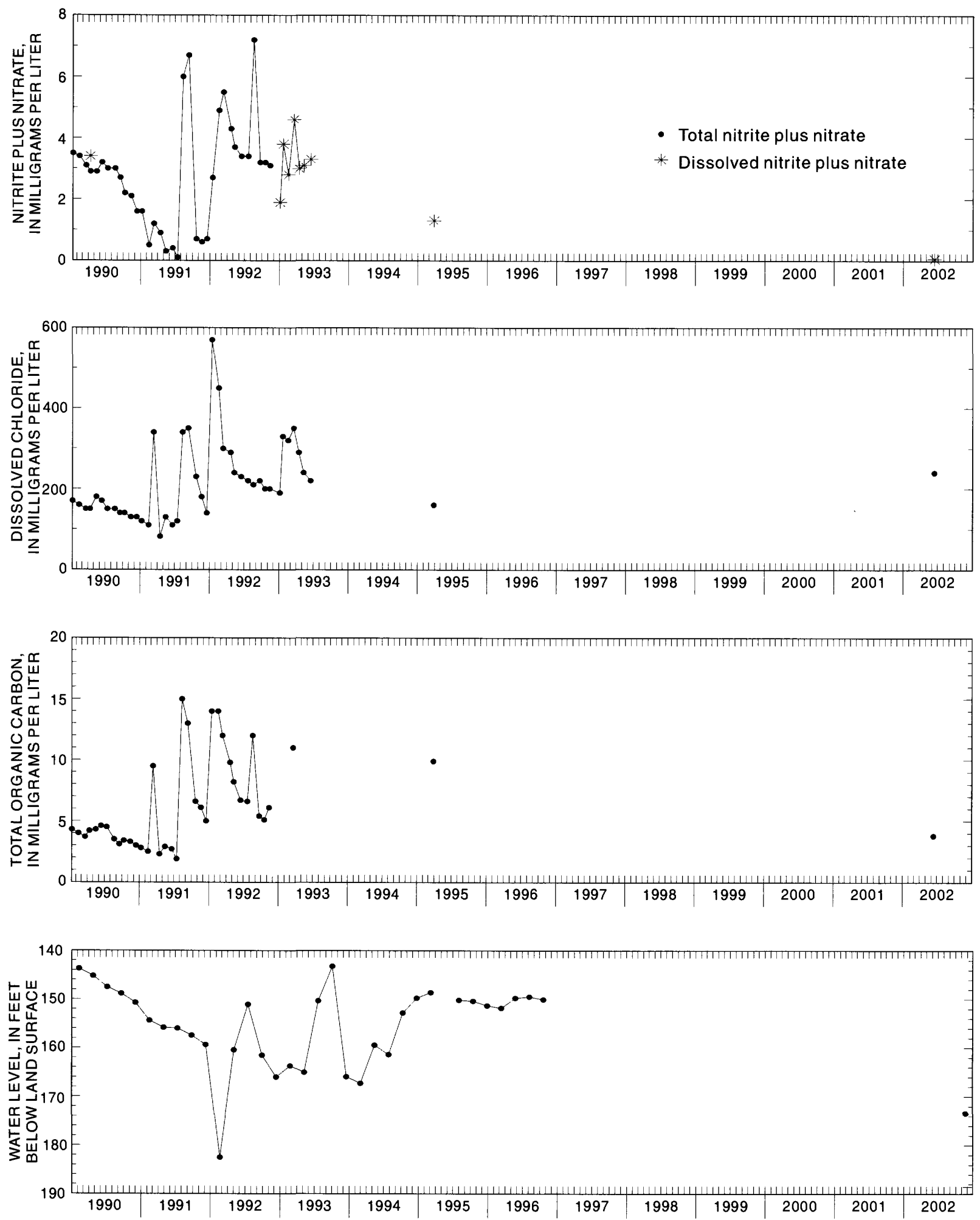

Figure 3. Concentrations of selected constituents and depth to water in well 8. 

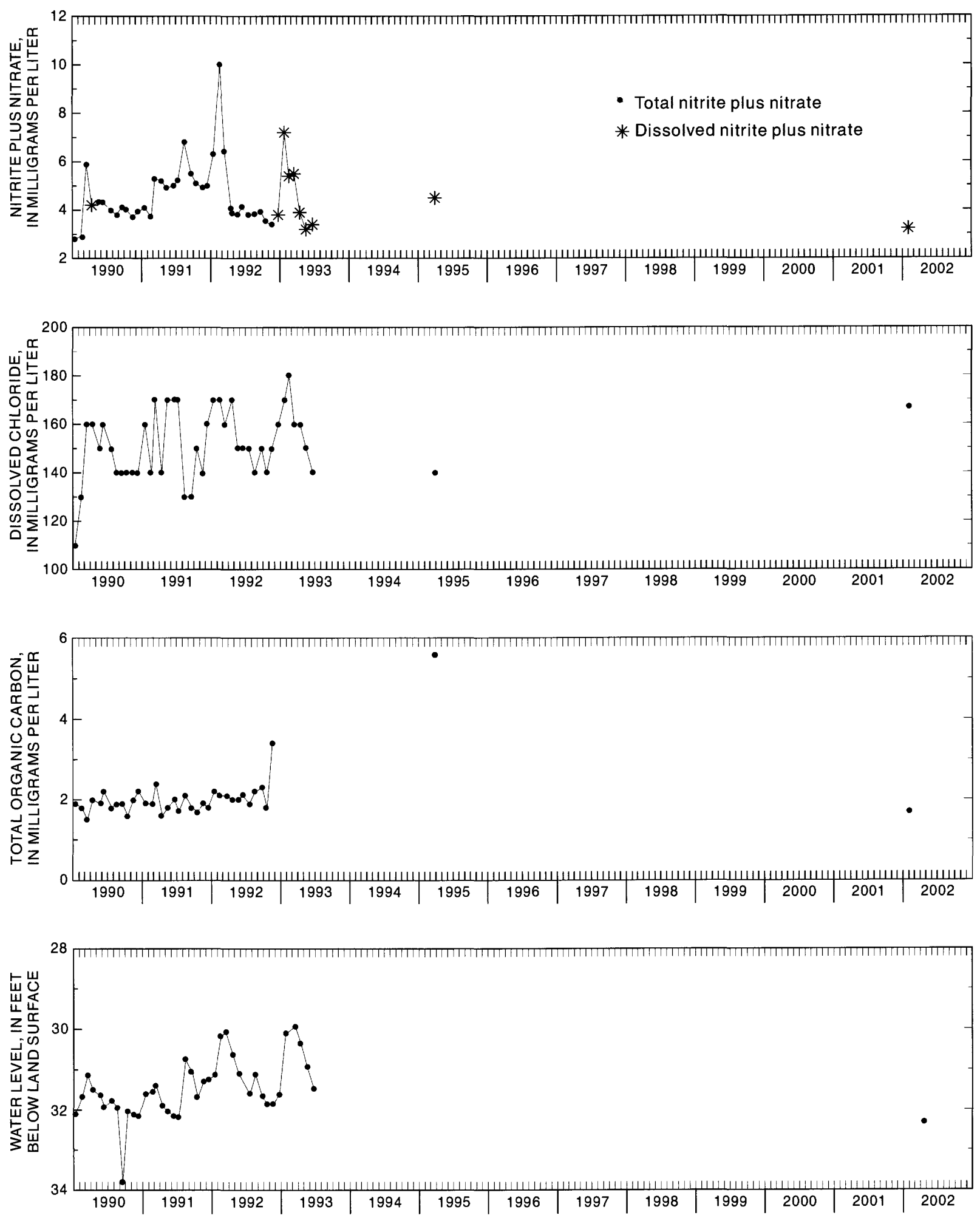

Figure 4. Concentrations of selected constituents and depth to water in well 12. 

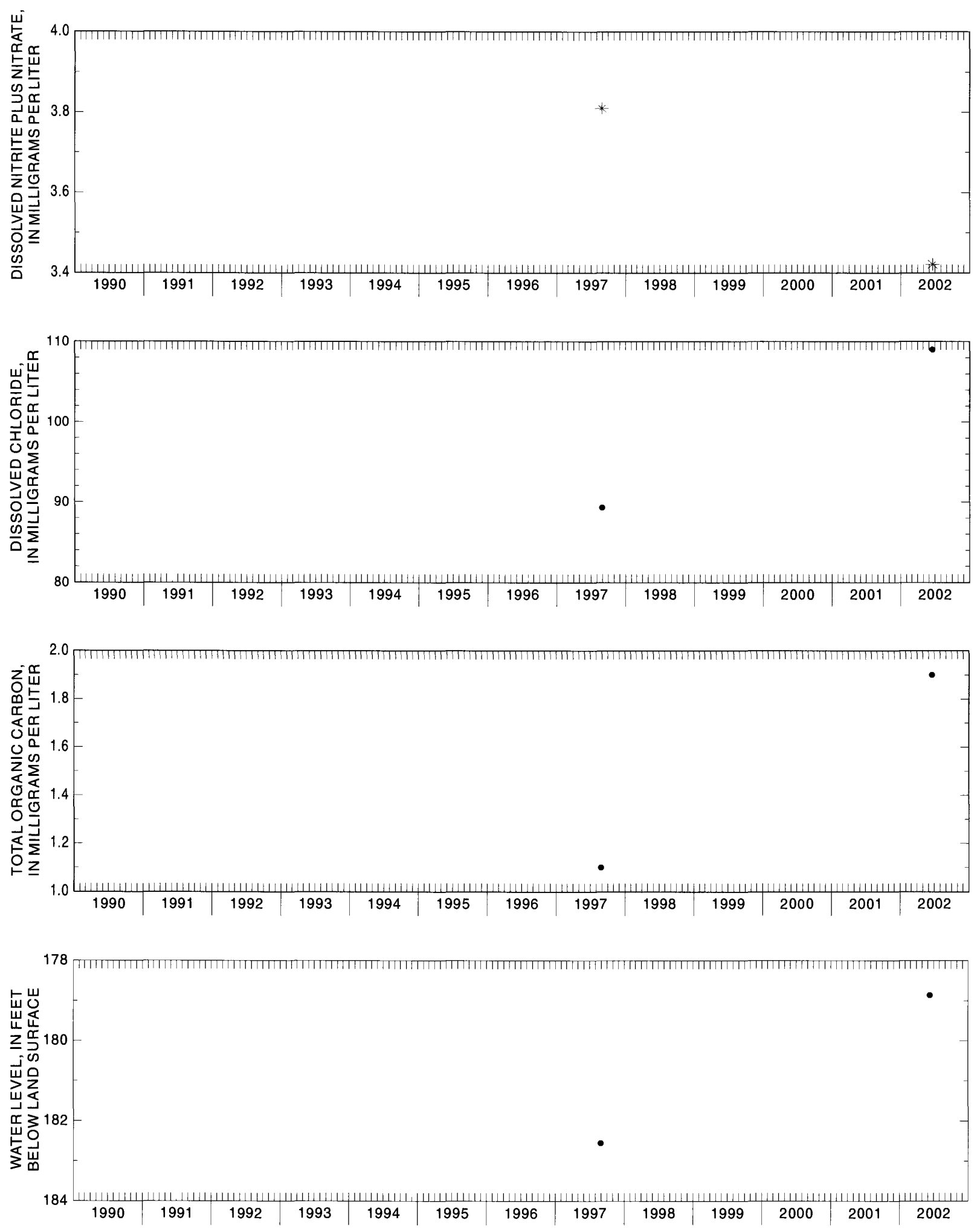

Figure 5. Concentrations of selected constituents and depth to water in well 13. 

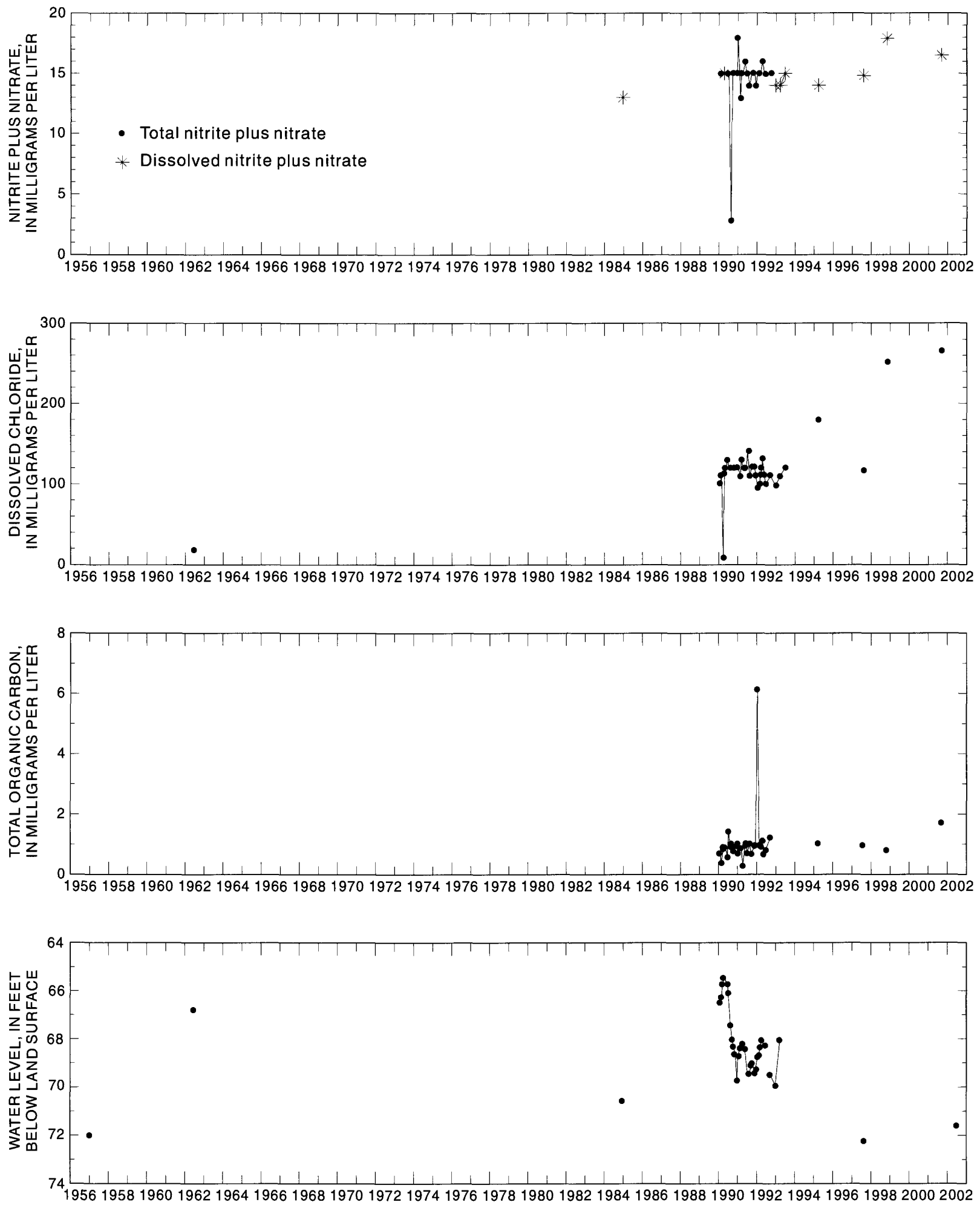

Figure 6. Concentrations of selected constituents and depth to water in well 14. 

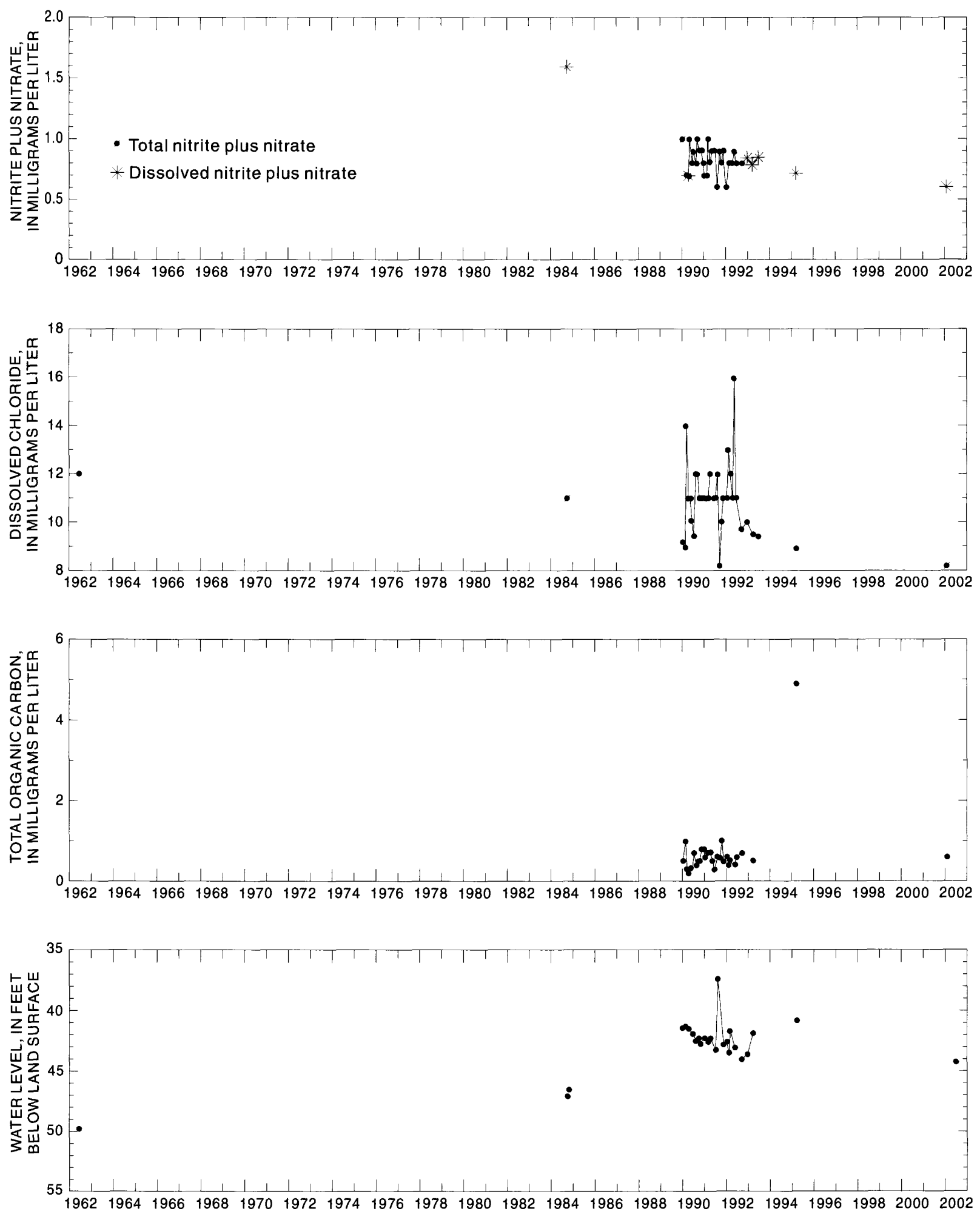

Figure 7. Concentrations of selected constituents and depth to water in well 15. 

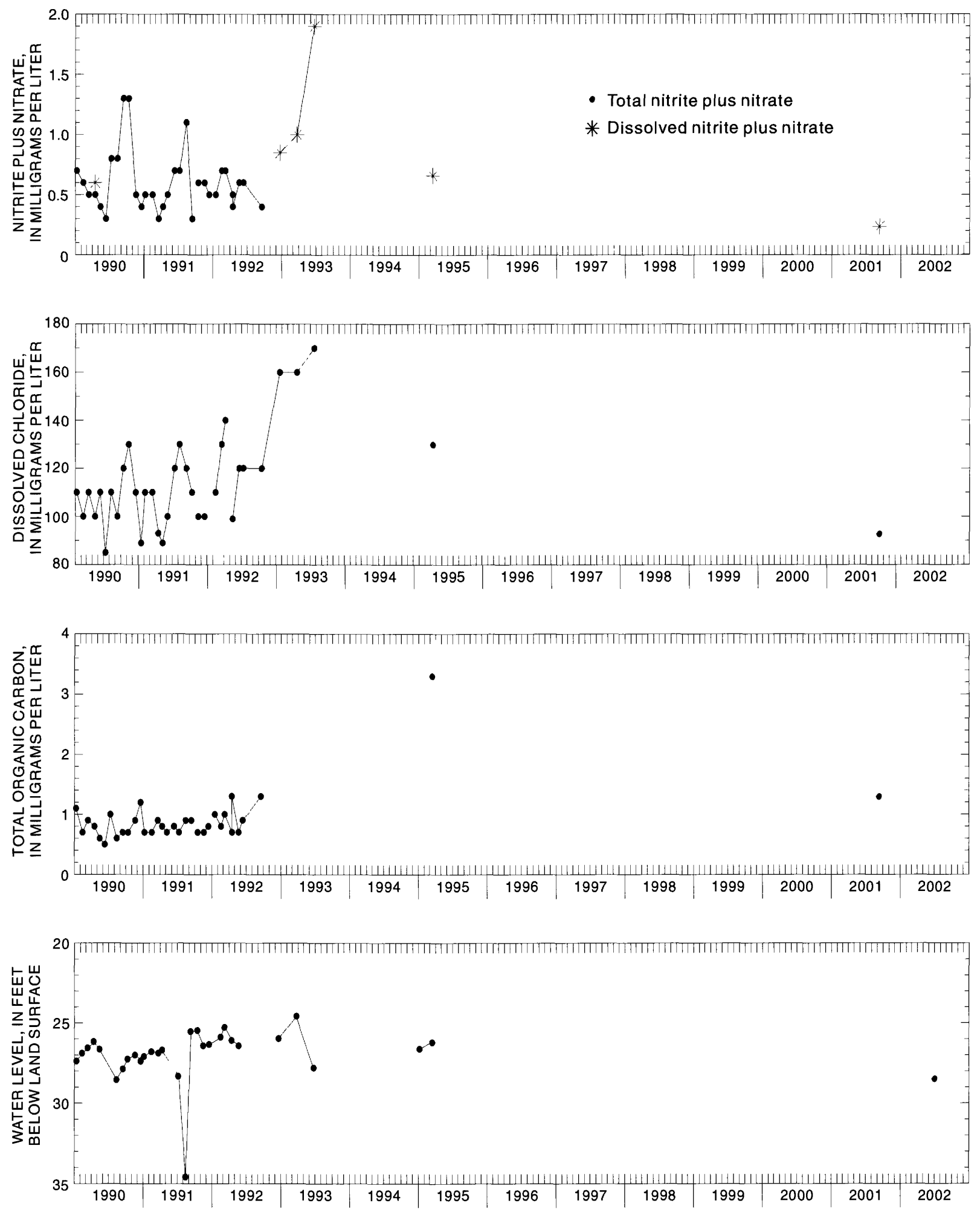

Figure 8. Concentrations of selected constituents and depth to water in well 17. 

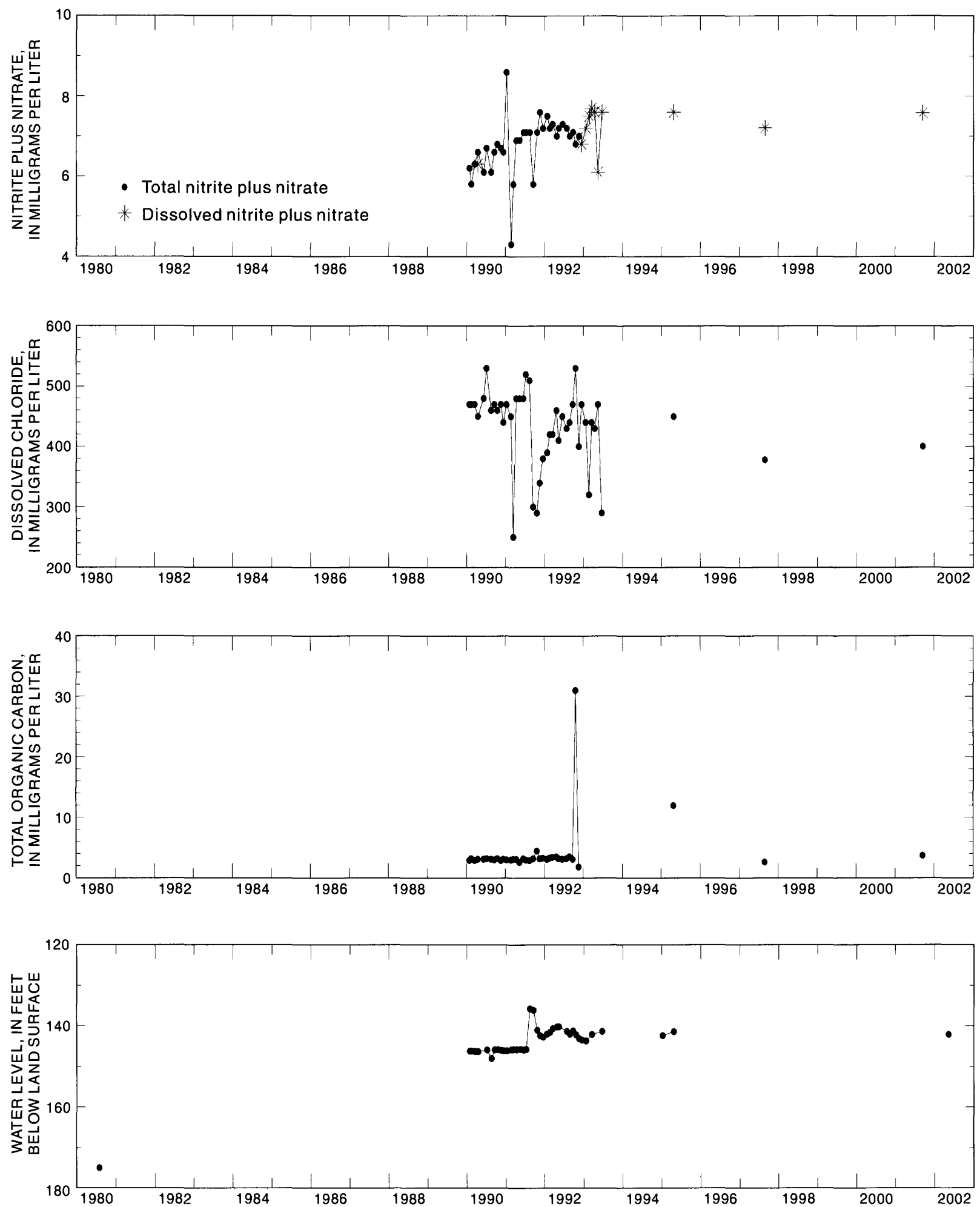

Figure 9. Concentrations of selected constituents and depth to water in well 19. 

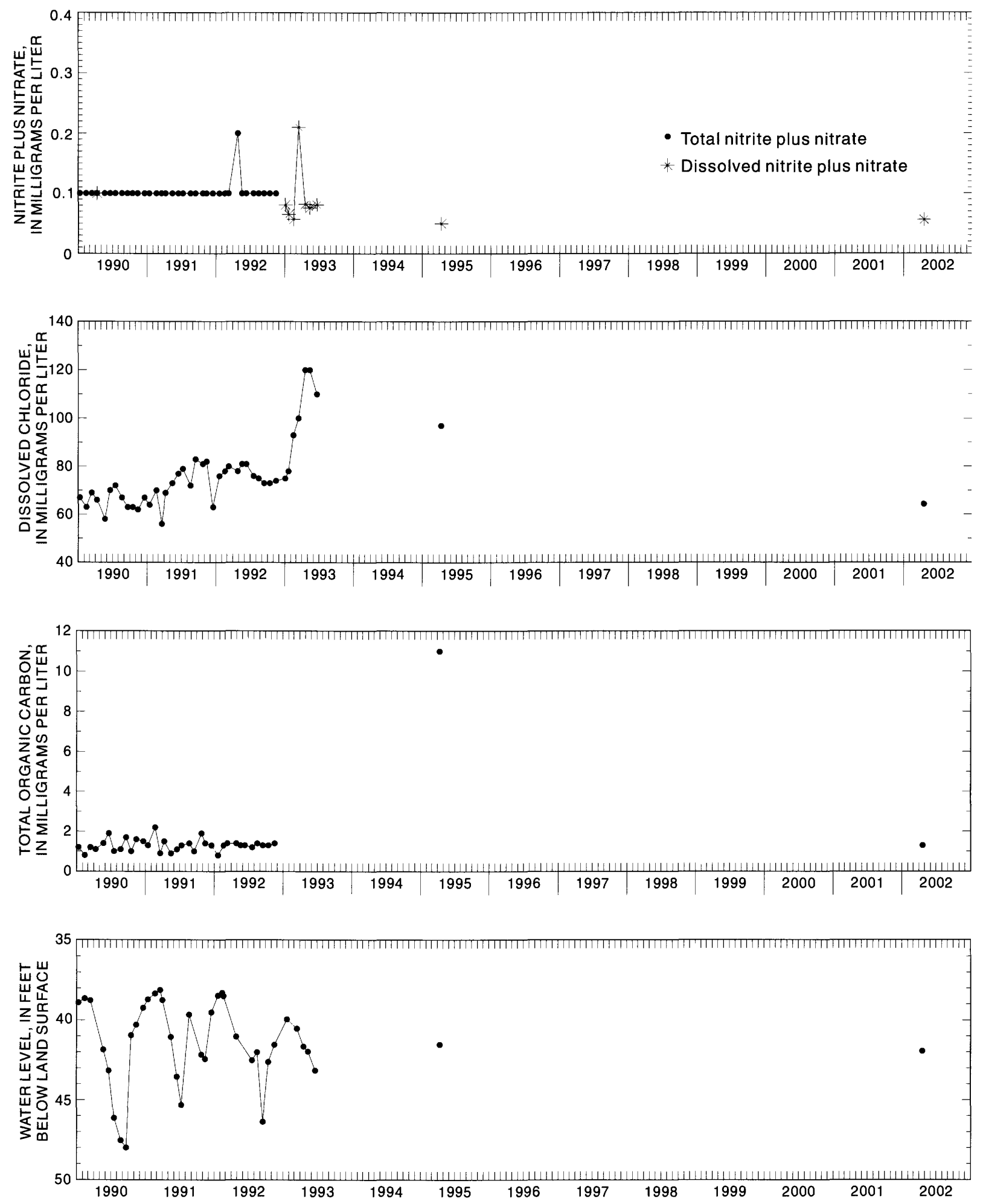

Figure 10. Concentrations of selected constituents and depth to water in well 20. 

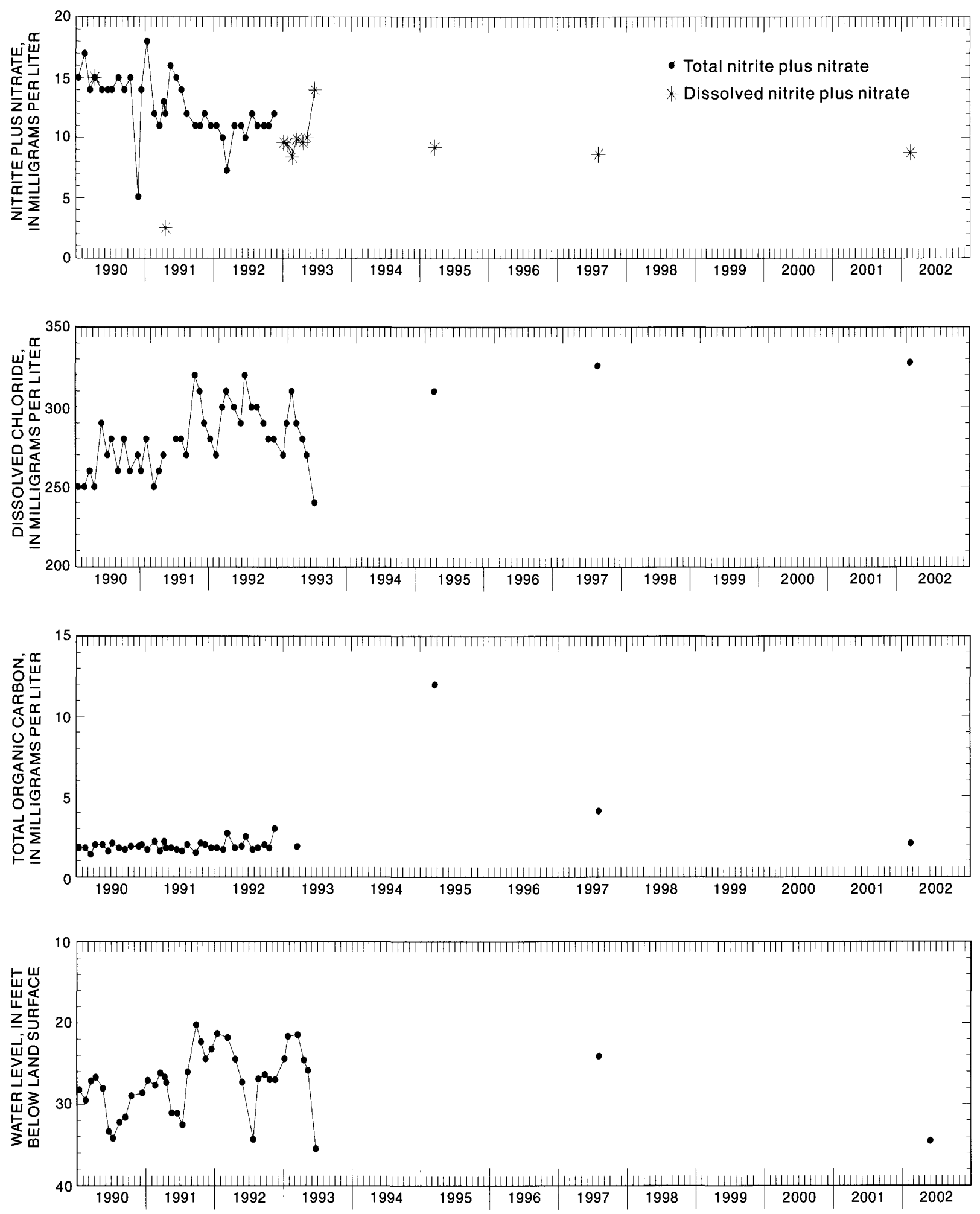

Figure 11. Concentrations of selected constituents and depth to water in well 21. 

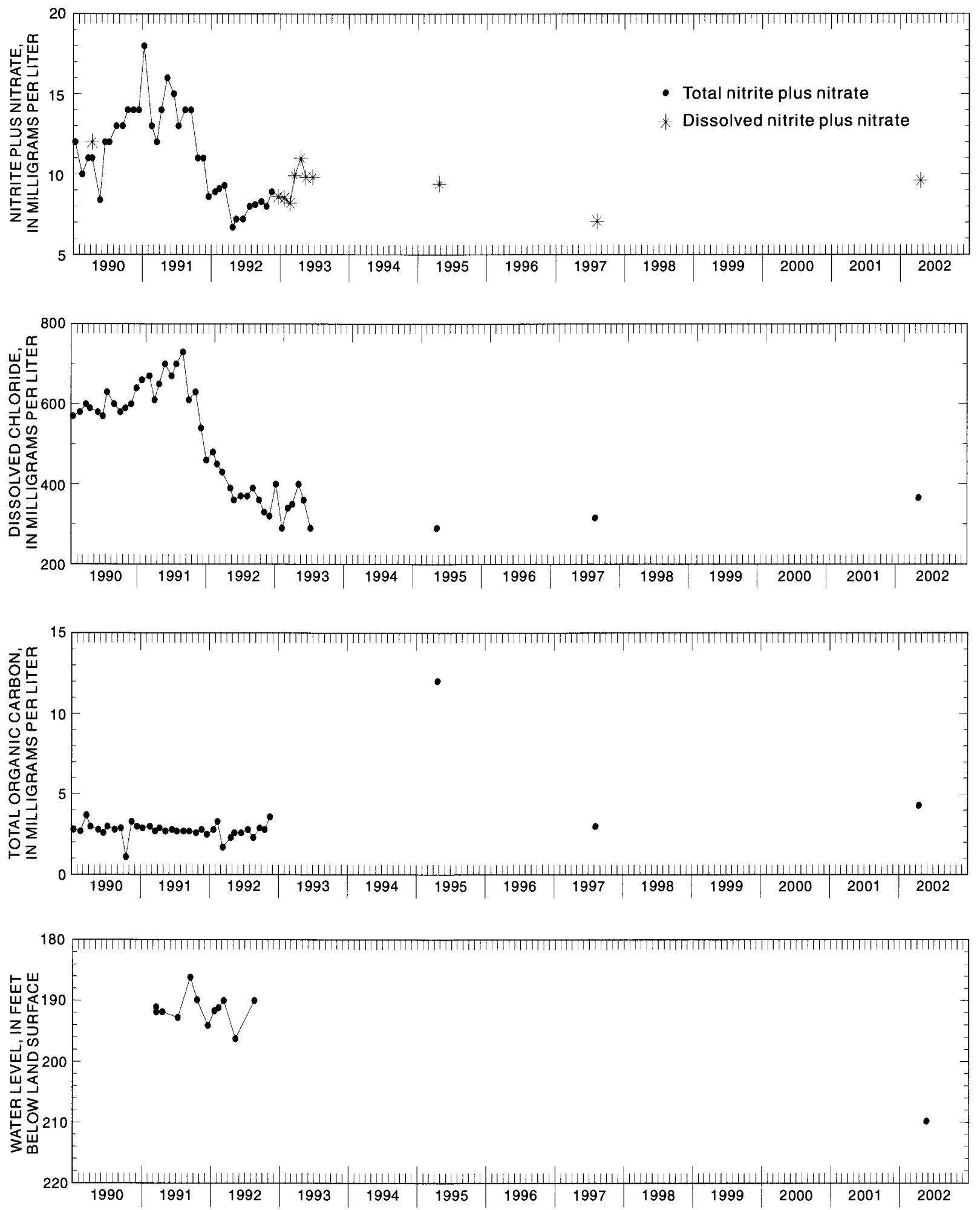

Figure 12. Concentrations of selected constituents and depth to water in well 23. 

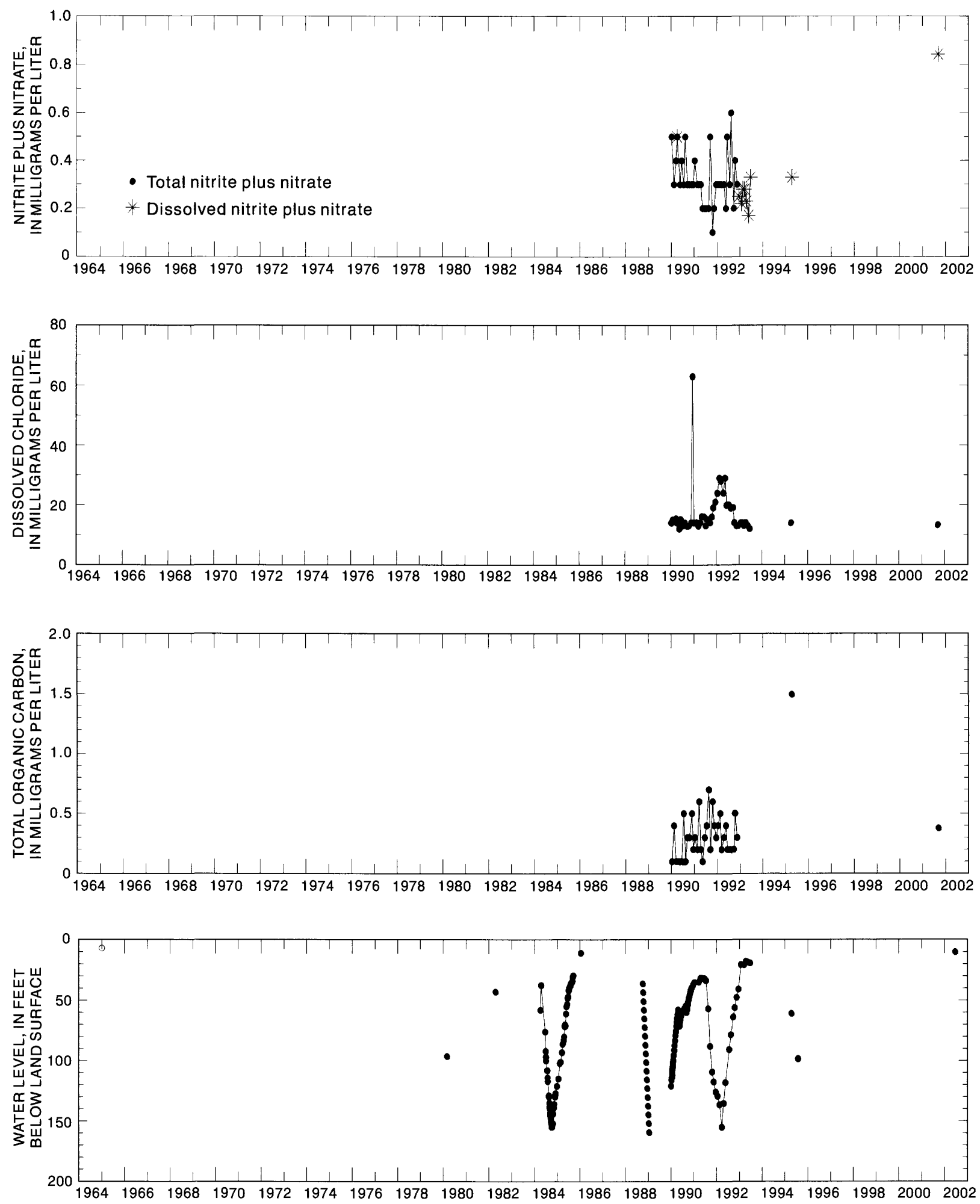

Figure 13. Concentrations of selected constituents and depth to water in well 24. 

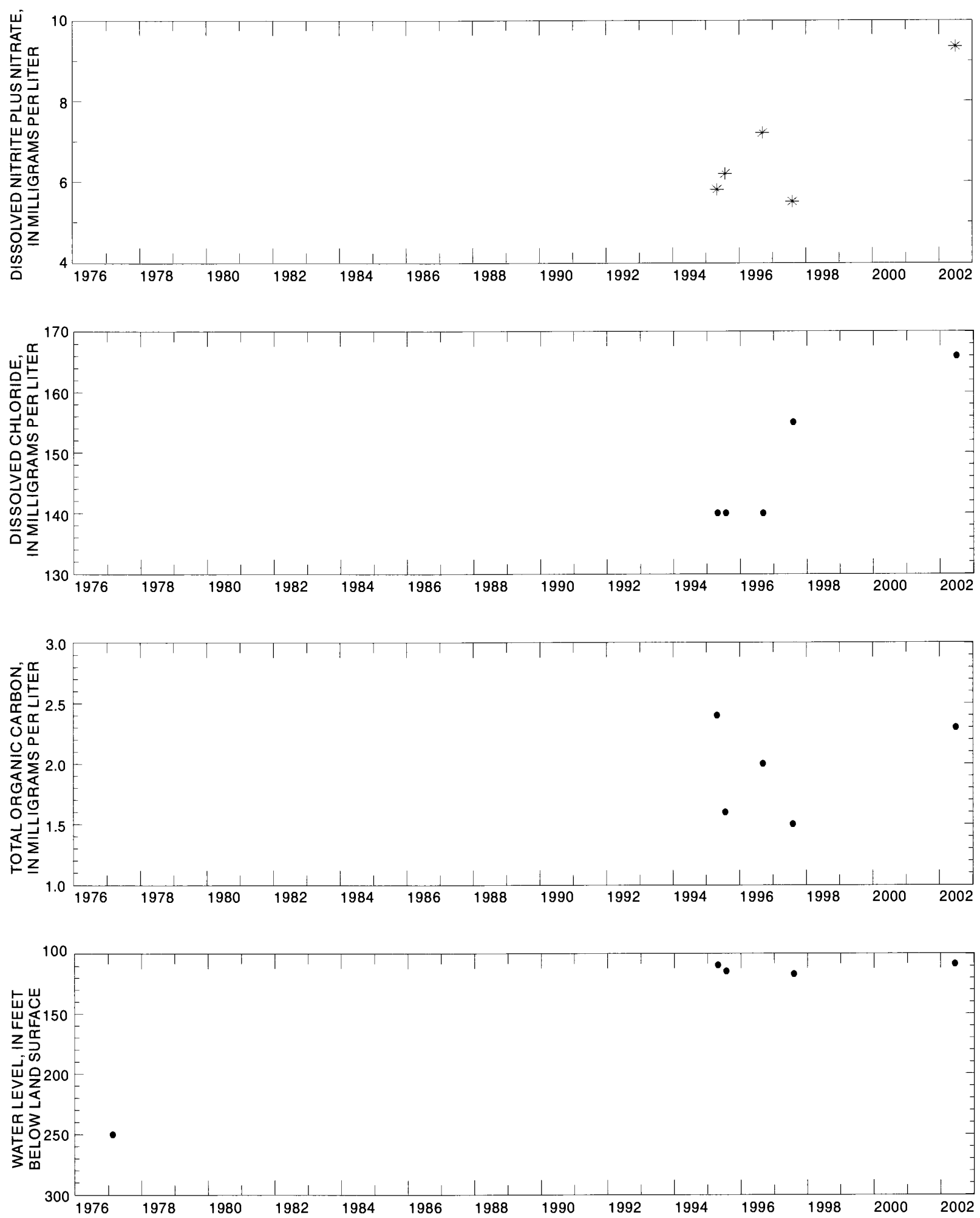

Figure 14. Concentrations of selected constituents and depth to water in well 25. 

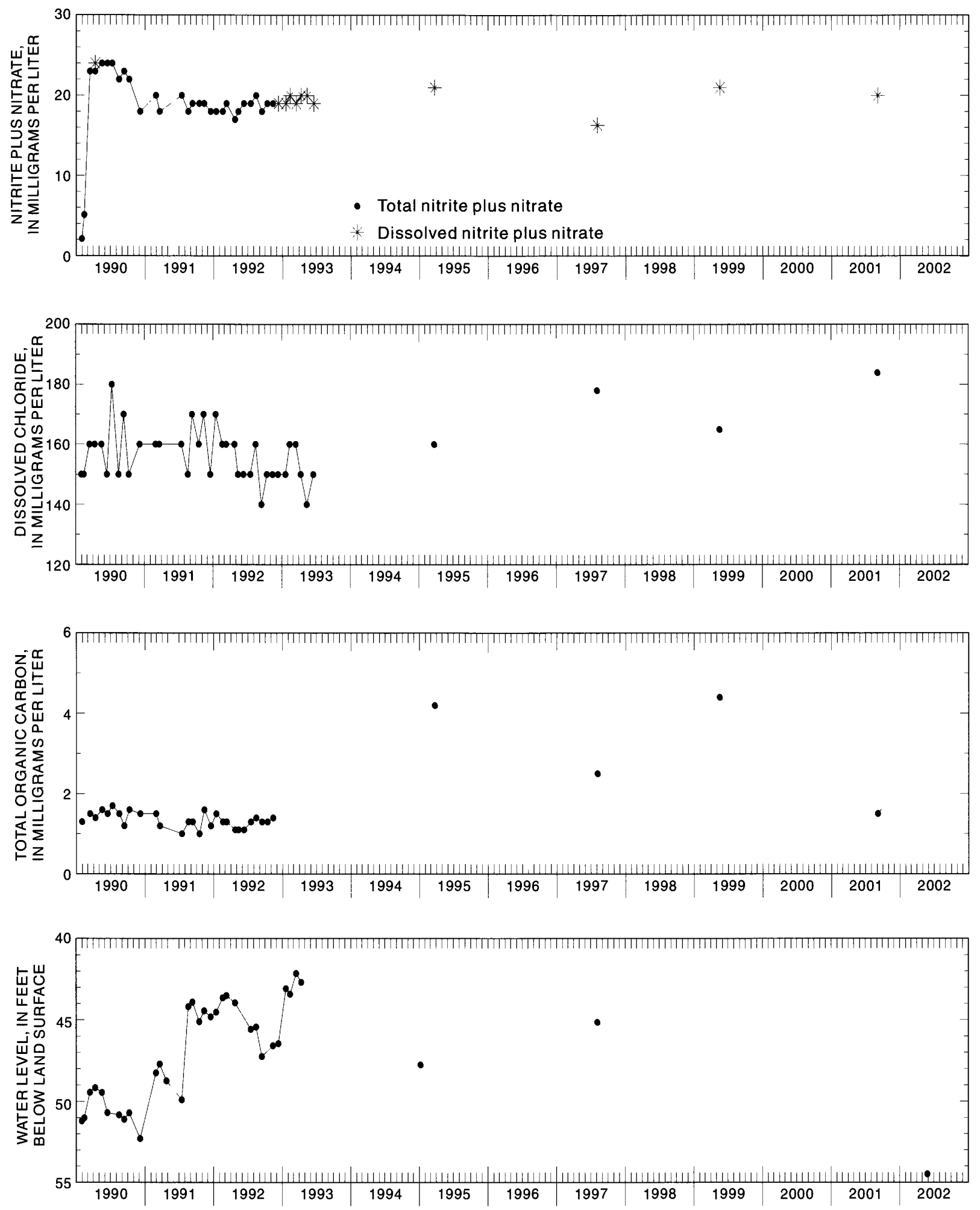

Figure 15. Concentrations of selected constituents and depth to water in well 26. 

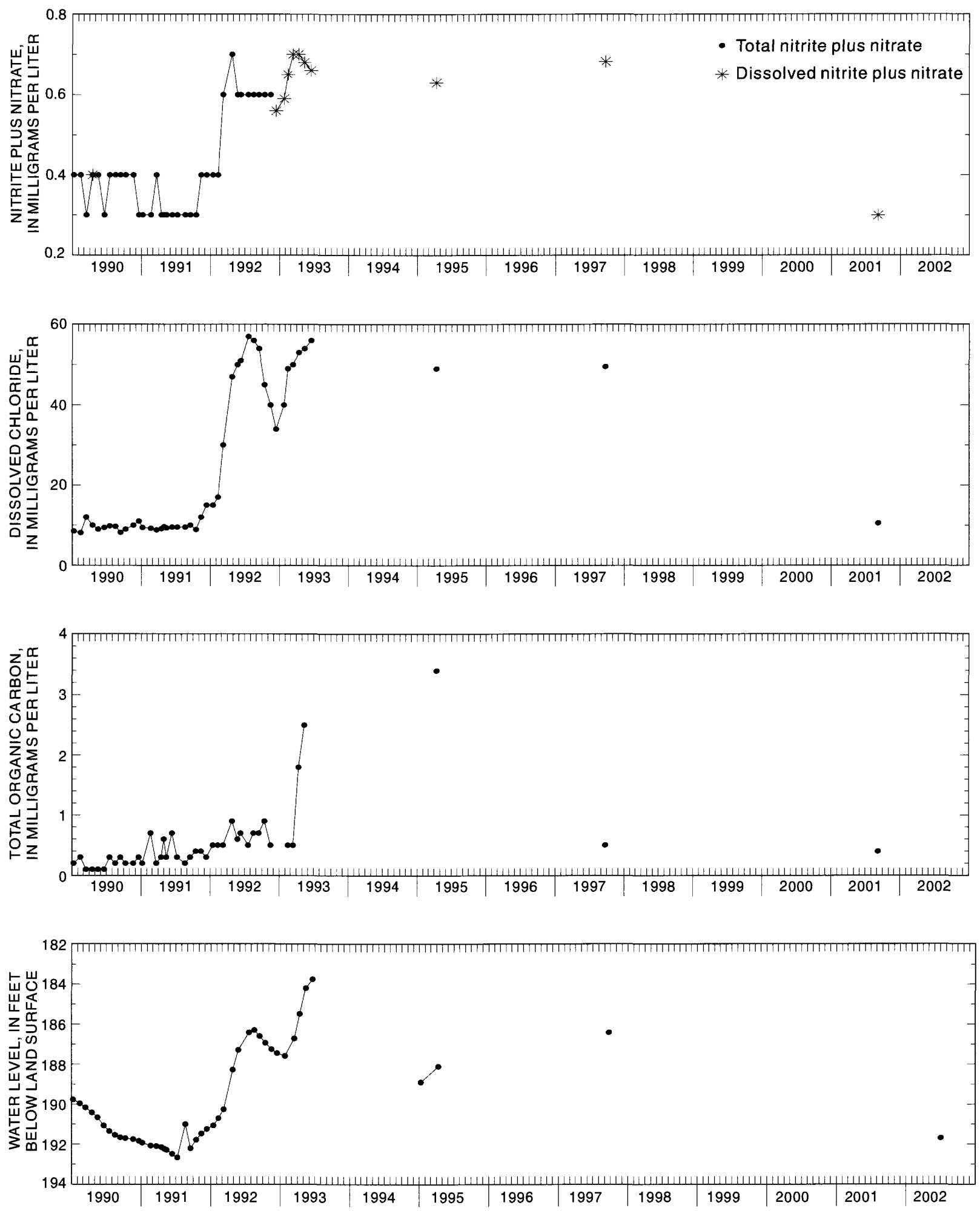

Figure 16. Concentrations of selected constituents and depth to water in well 29. 

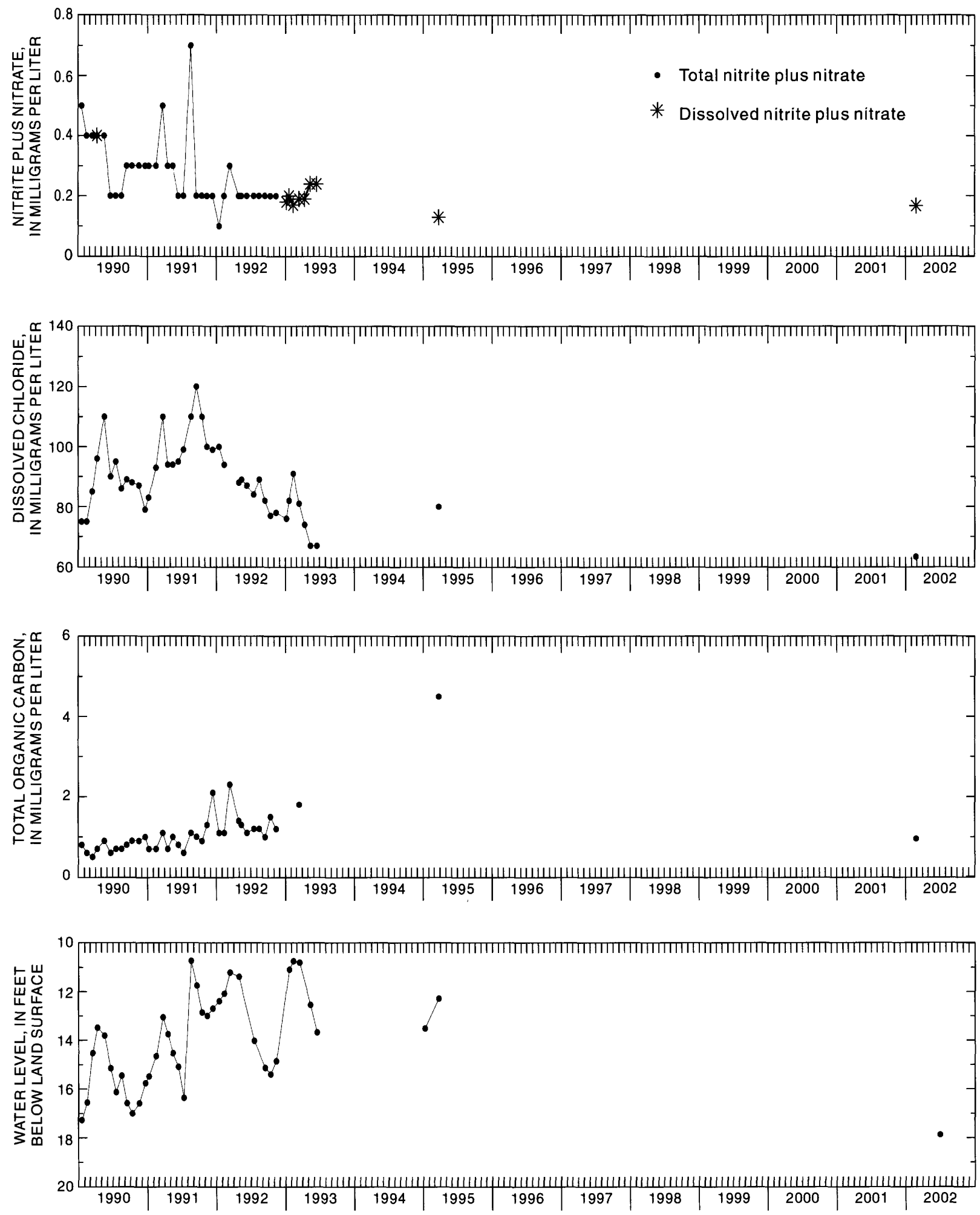

Figure 17. Concentrations of selected constituents and depth to water in well 30. 

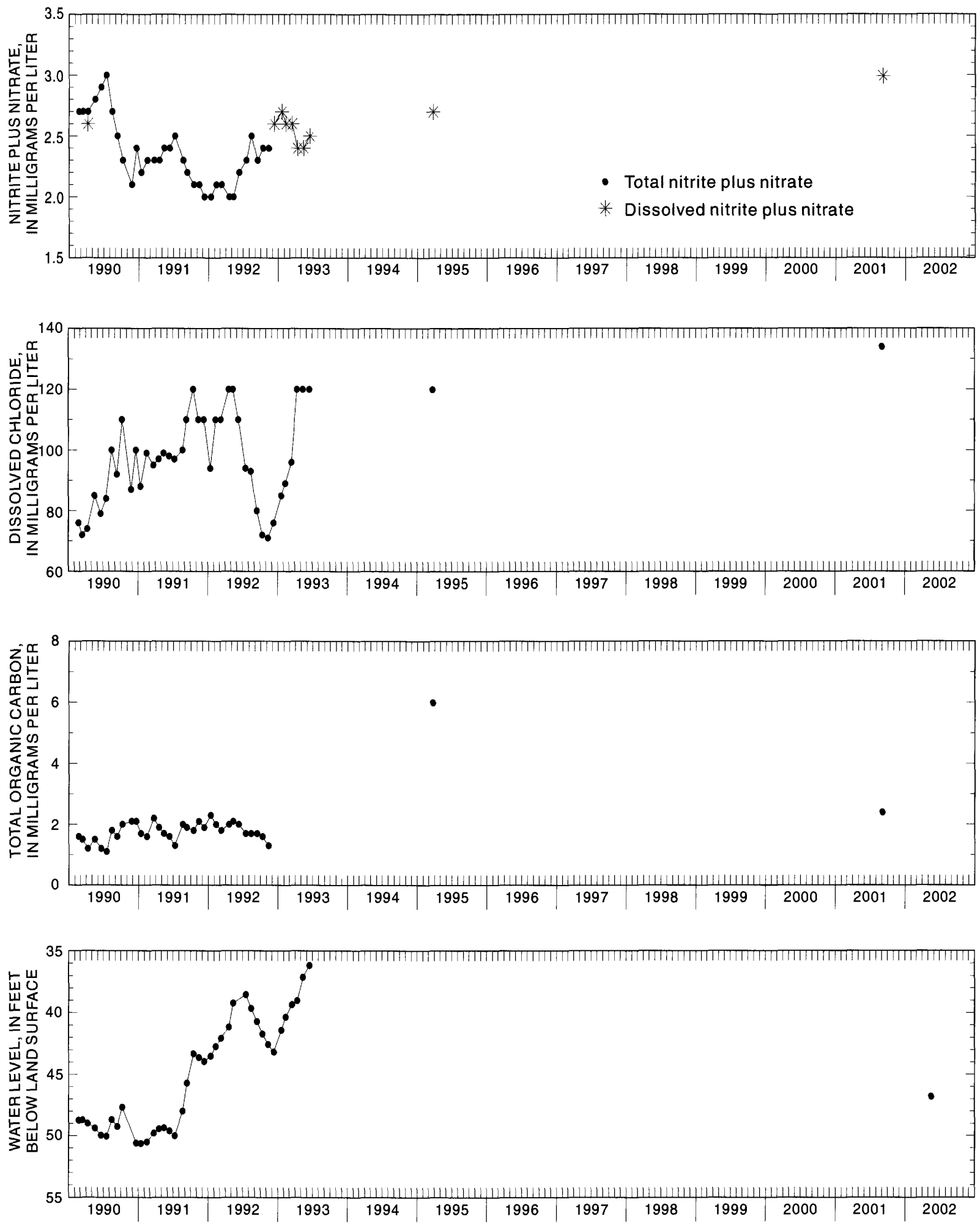

Figure 18. Concentrations of selected constituents and depth to water in well 31. 

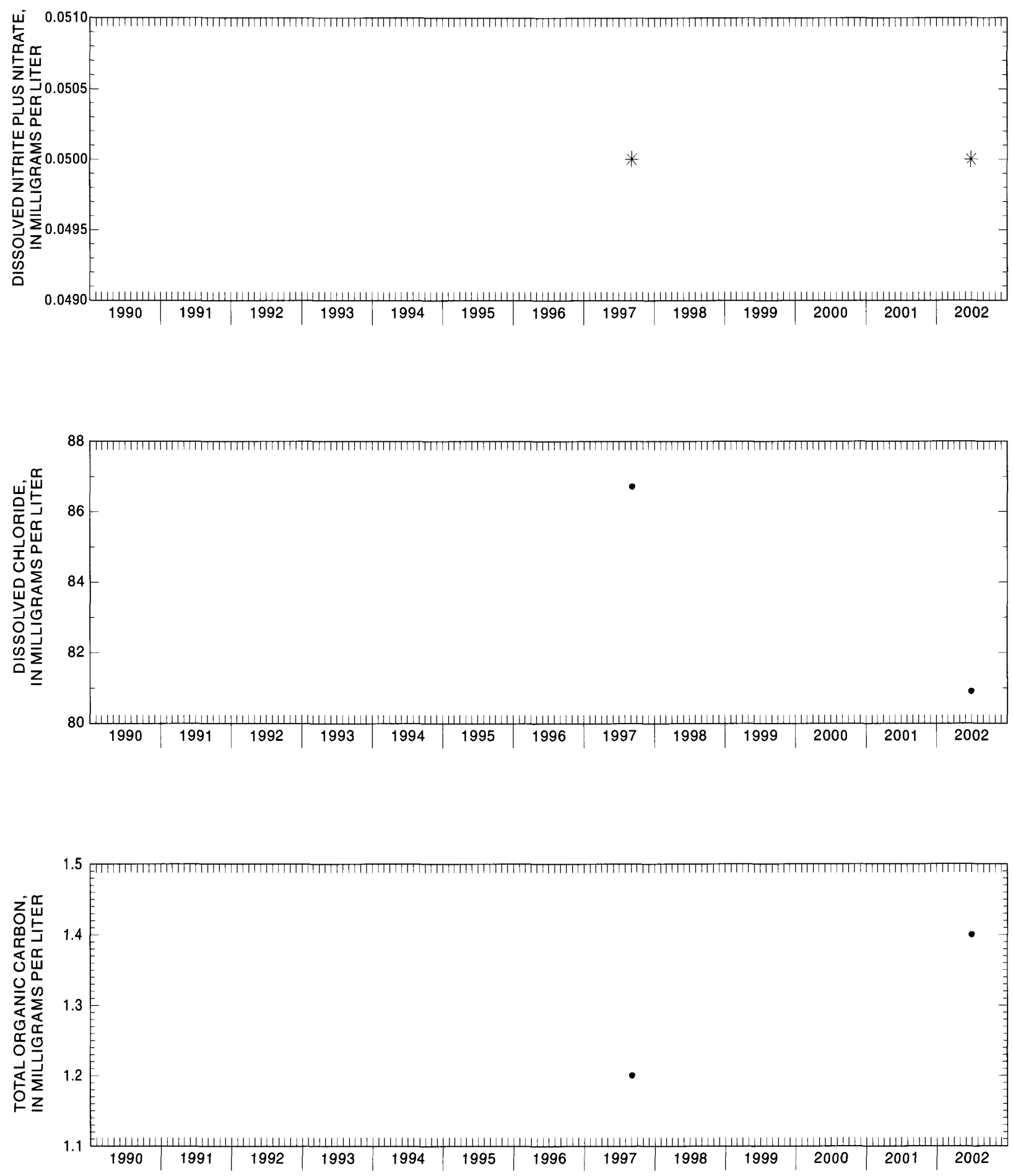

Figure 19. Concentrations of selected constituents in well 4. 

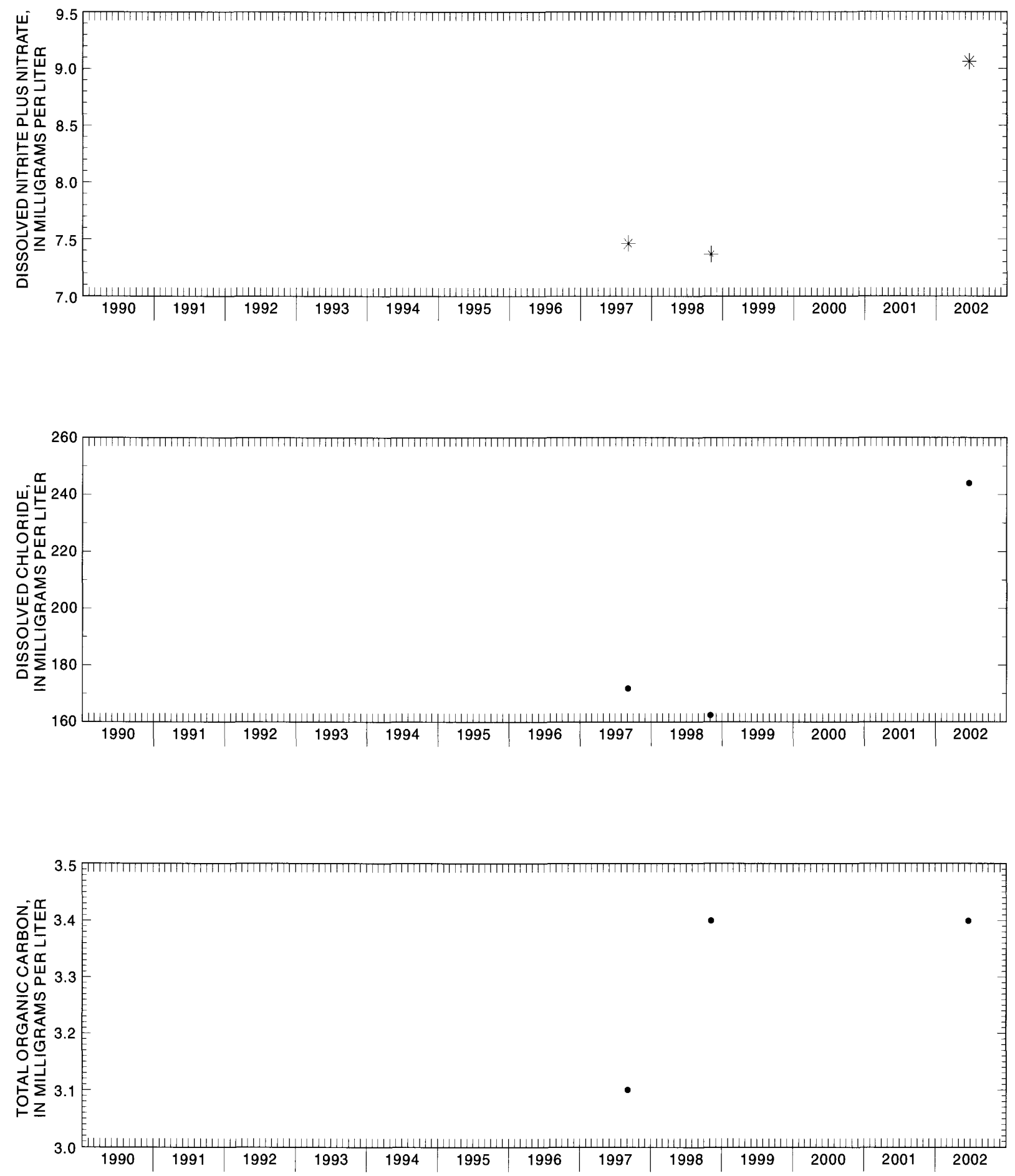

Figure 20. Concentrations of selected constituents in well 5. 

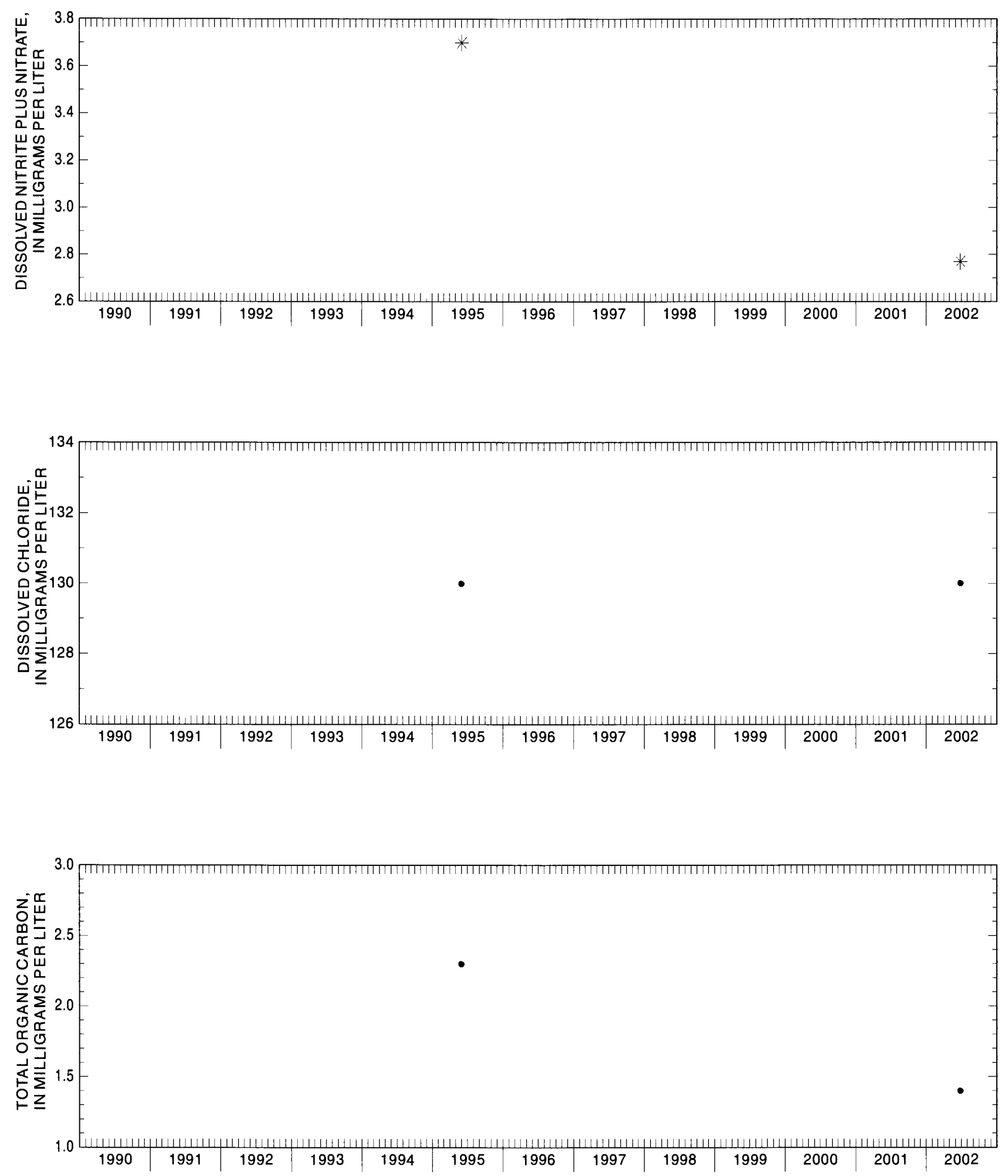

Figure 21. Concentrations of selected constituents in well 6 . 

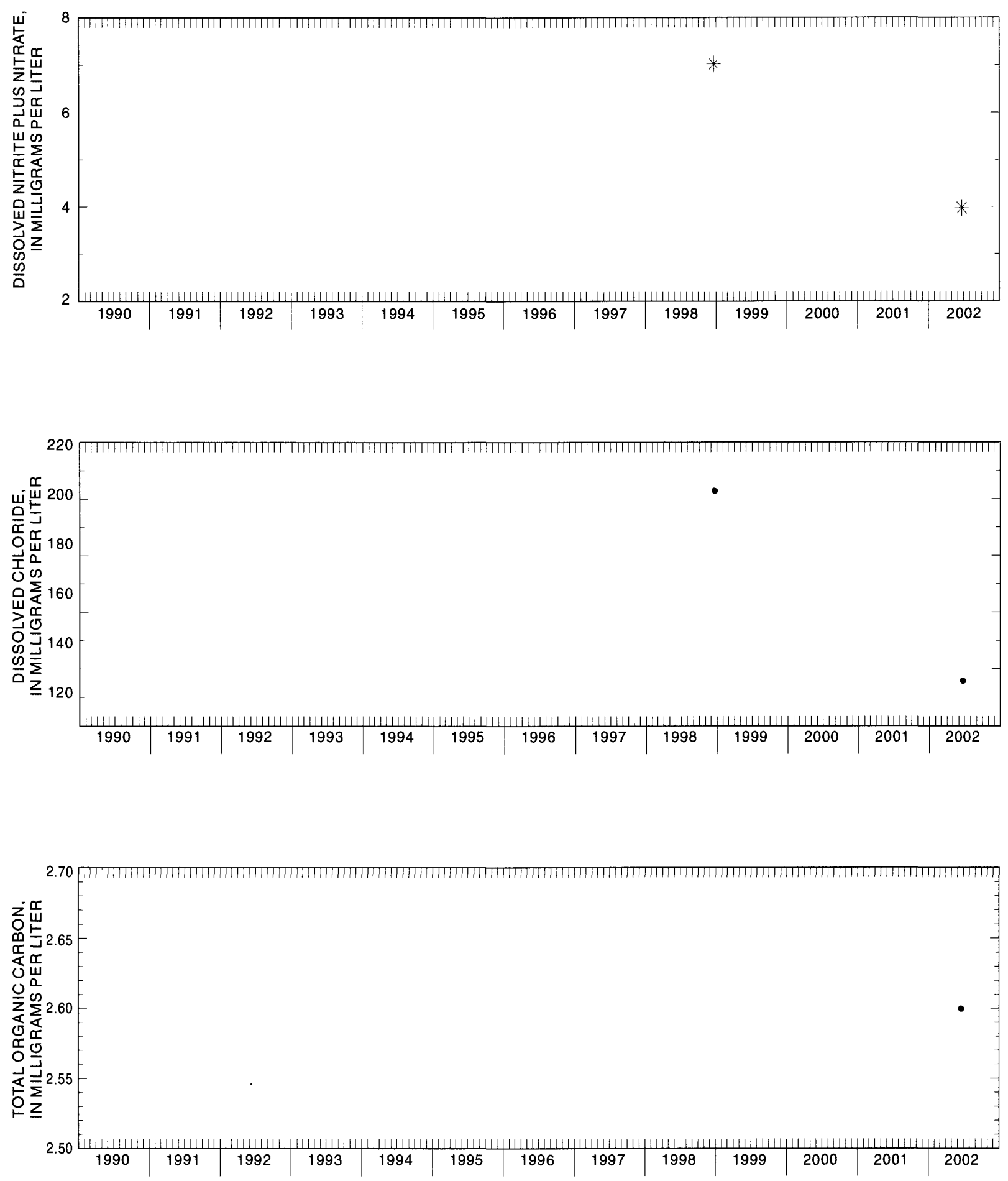

Figure 22. Concentrations of selected constituents in well 7. 

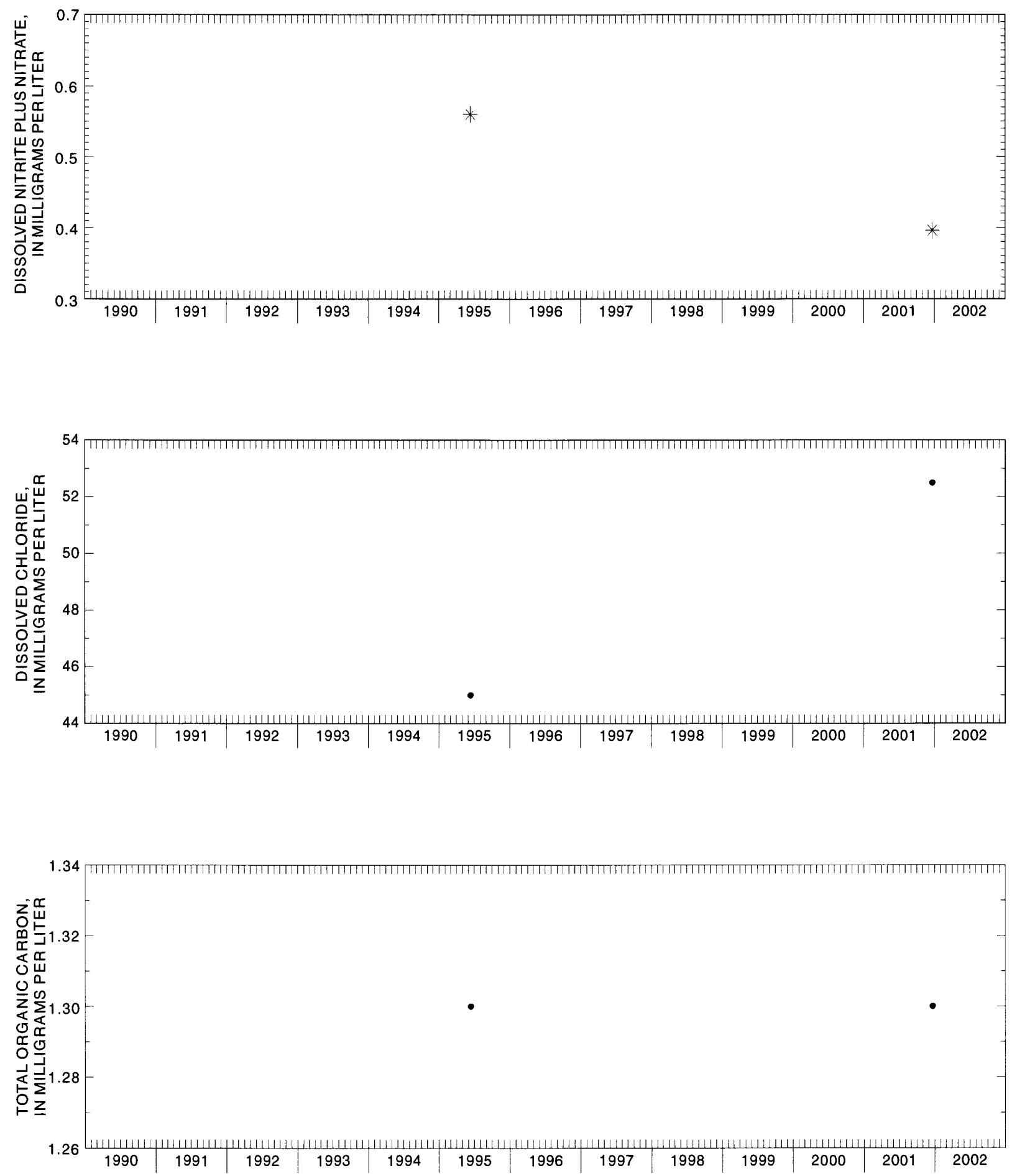

Figure 23. Concentrations of selected constituents in well 11 . 

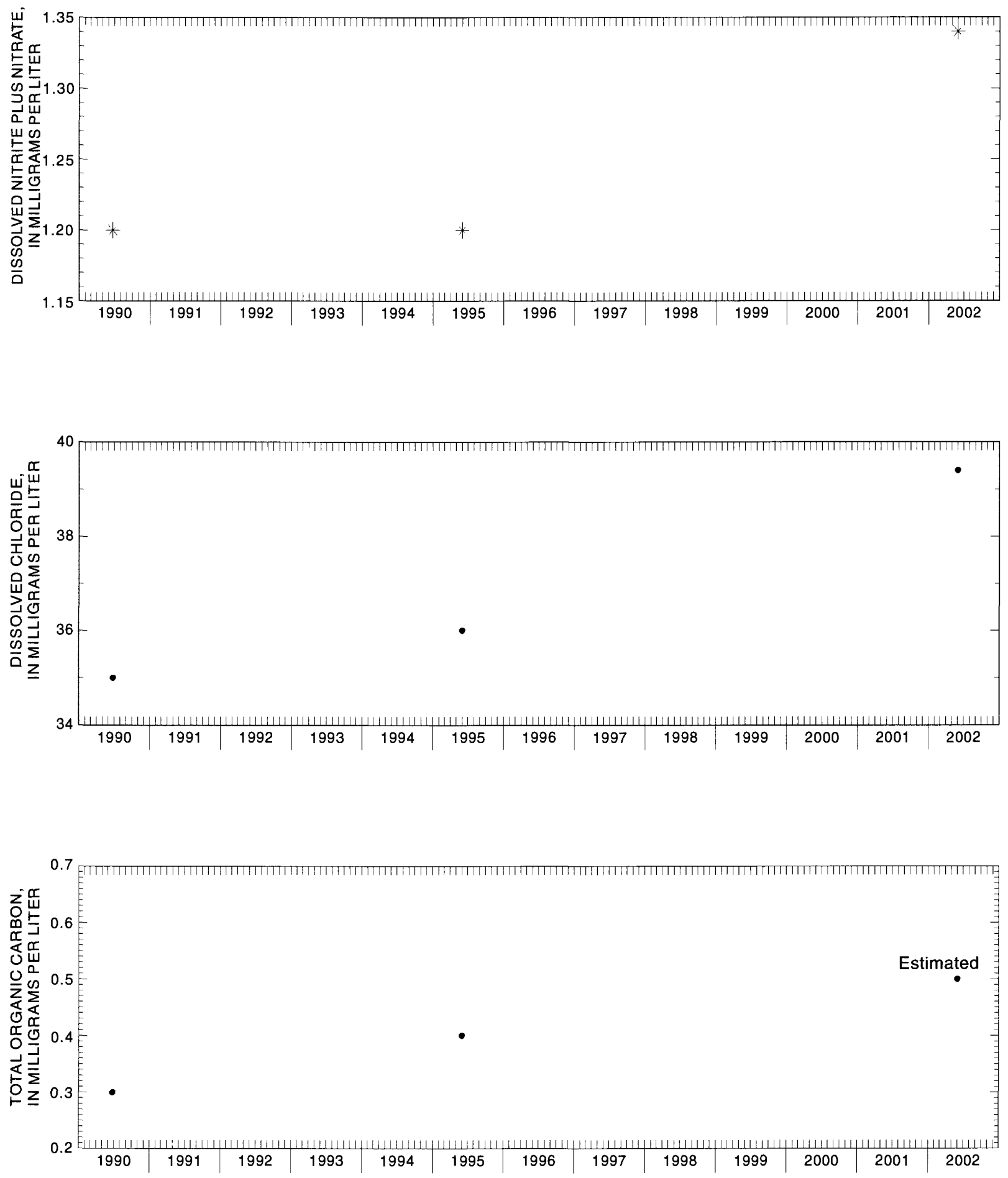

Figure 24. Concentrations of selected constituents in well 16. 

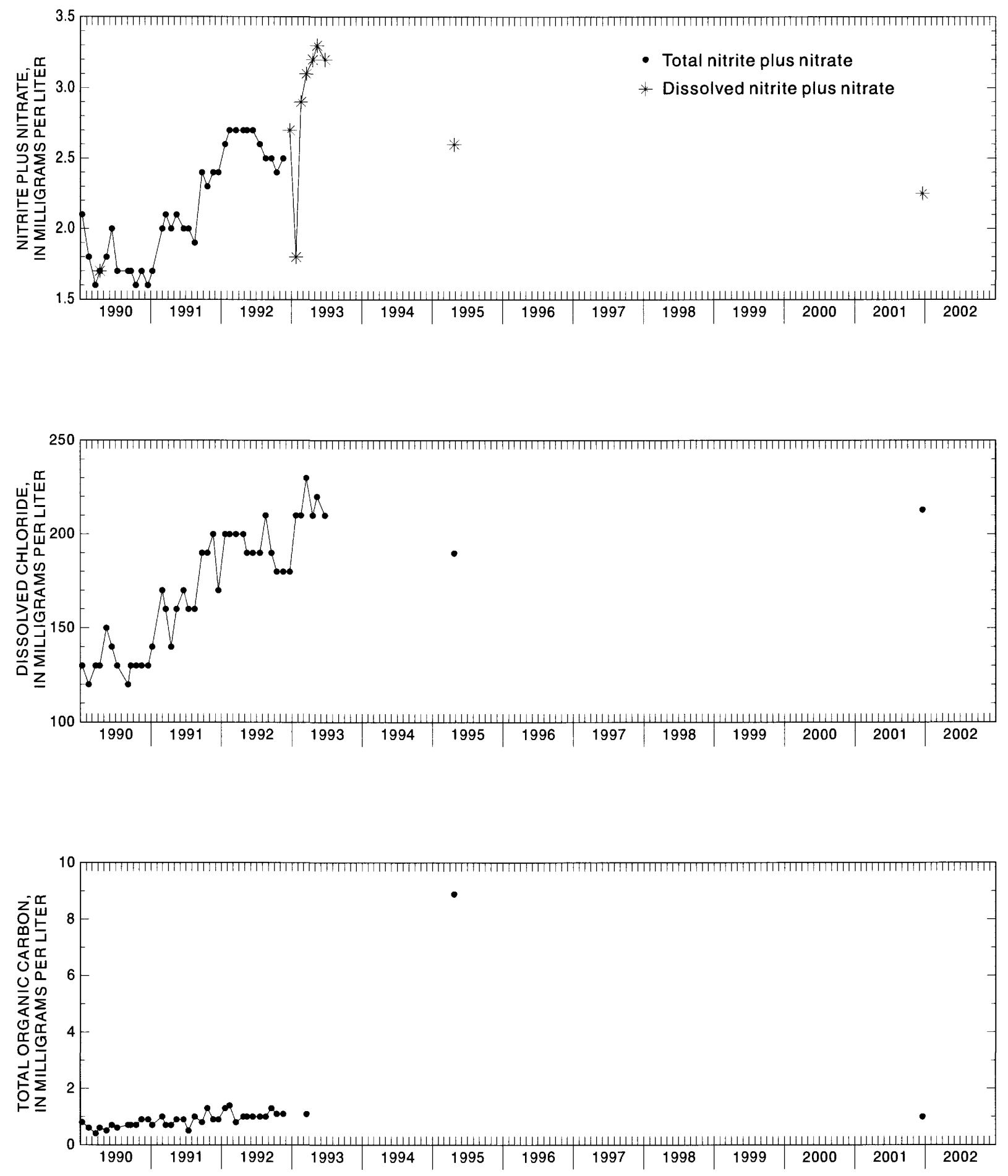

Figure 25. Concentrations of selected constituents in well 18. 

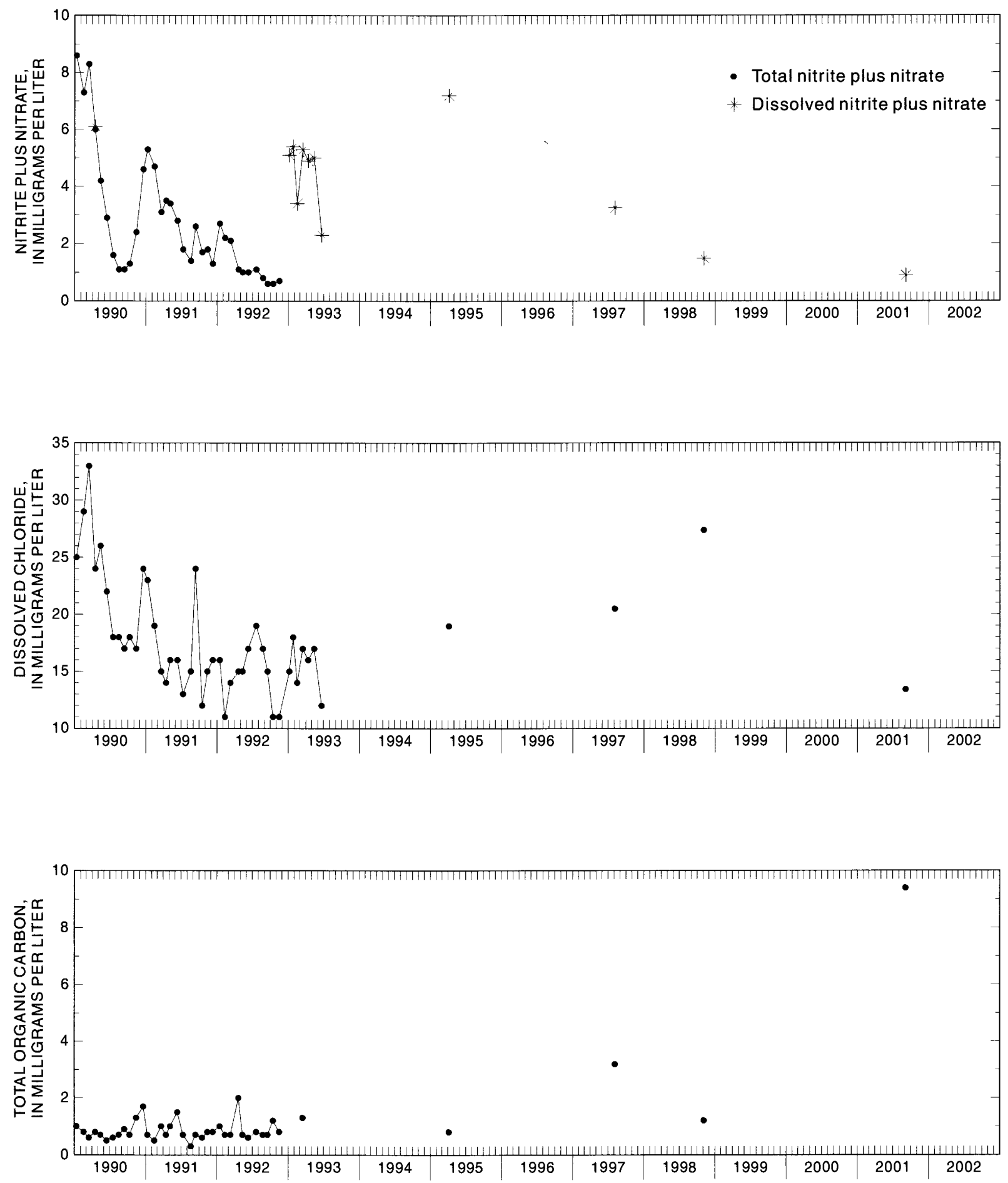

Figure 26. Concentrations of selected constituents in well 22. 

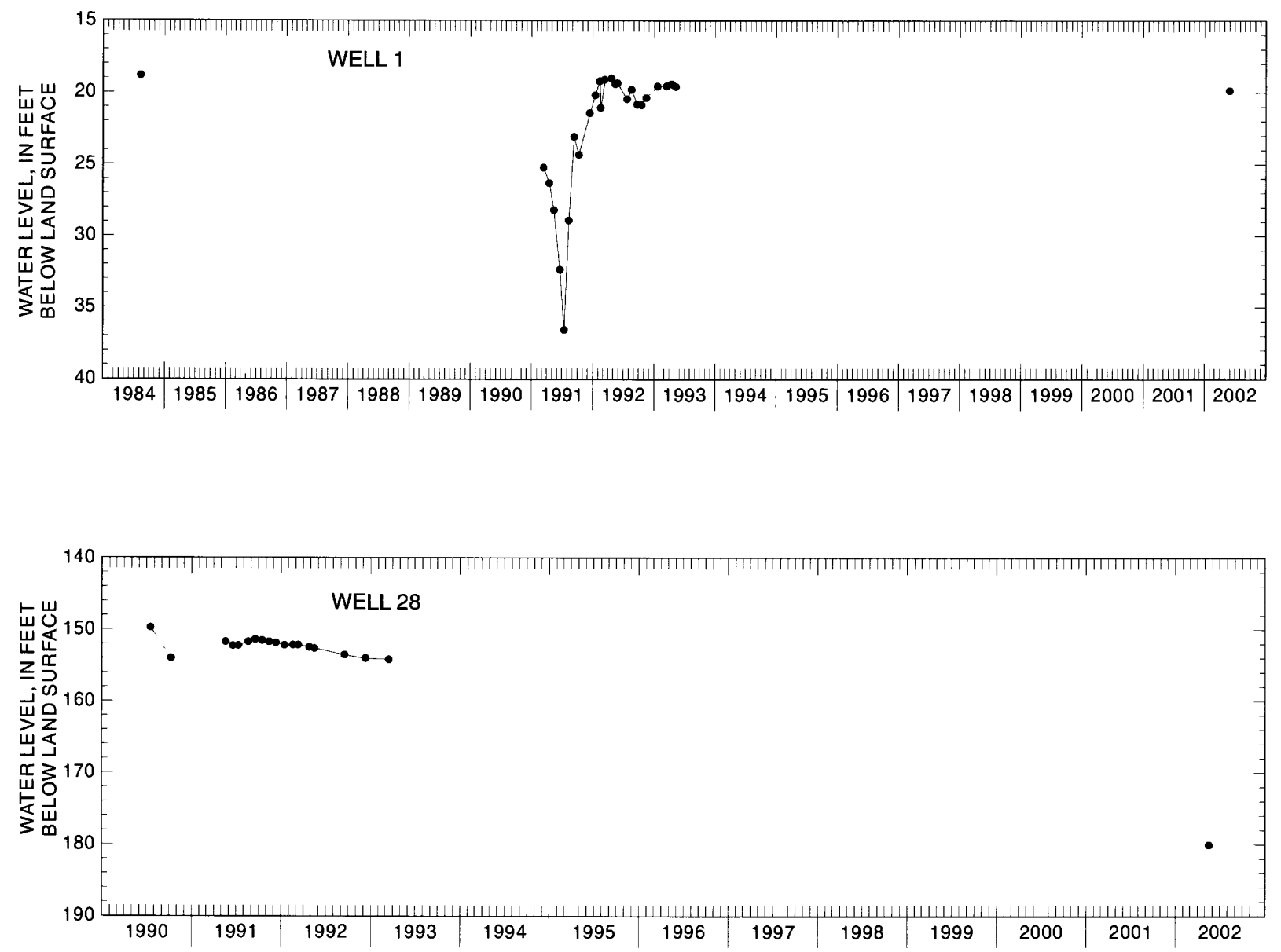

Figure 27. Depth to water in wells 1 and 28. 
U.S. Department of the Interior

U.S. Geological Survey, WRD

5338 Montgomery Blvd. NE, Suite 400

Albuquerque, NM 87109-1311

BOOK RATE 